\title{
YABANCILAR VE ULUSLARARASI KORUMA HUKUKUNDA KALICI BİR ÇÖZÜM OLARAK YEREL ENTEGRASYON
}

DOI: $10.21492 /$ inuhfd.387041

\author{
Mesut AYGÜN* \\ Cansu KAYA**
}

\begin{abstract}
Özet
Bir tarafin zulmetme diğer tarafinsa bu zulümden kaçması eski zamanlardan bu yana vardır. Modern devletlerin oluşması ile birlikte, sınırları belirginleşmiş devlet topraklarındaki zulümden kaçan kişiye, ikame bir korumanın sağlanması ise daha yakın bir tarihe dayanmaktadır. Kişiye devletinin sağlamadığı veya artık sağlayamadığı ulusal korumanın uluslararası camia tarafından sağlandığı bu ikame koruma türü uluslararası korumadır. Genel kabul görmüş görüşe göre, uluslararası koruma ikame koruma ile başlar ve korunan kişiye kalıcı çözüm sağlanması ile sona erer.

Uluslararası hukukta, uluslararası koruma kapsamında yer alan kişilere kalıcı çözüm sağlanması amacıyla kabul görmüş üç yöntemden birisi yerel entegrasyondur. Yerel entegrasyon ile kişiye vatandaşa tanınan birçok hak tanınarak topluma entegre olması sağlanmakta ve sahip olduğu statü sona ermektedir. Yabancılar ve Uluslararası Koruma Kanunu'nun 2014 tarihinde yürürlüğe girmesi ile yabancıların ülkeye entegre olmaları yönündeki düzenleme ilk defa Türk hukukunda yerini almıştır. Bu araştırmanın konusunu, yabancı kişilerin ülkeye uyum sağlamaları için uluslararası hukukta kişilere sağlanan haklar, var olan hukuki düzenlemeler ve benzer haklar ile hukuki düzenlemelerin iç hukukta nasıl ele alındığı oluşturur.
\end{abstract}

Anahtar Kelimeler: Yabanc1lar ve Uluslararası Koruma Kanunu, uluslararas1 koruma, mülteci hukuku, yerel entegrasyon, sosyal haklar, vatandaşl1k.

\section{THE LOCAL INTEGRATION AS A DURABLE SOLUTION IN FOREIGNERS AND INTERNATIONAL PROTECTION LAW}

\footnotetext{
Abstract

Persecution of one party and fleeing of the persecuted one exist from ancient times. With the formation of modern states, it is however more recent to provide a person fleeing from an oppression in a state with distinctive borders with substitute protection. This type of substitute protection in which the protection cannot provided by the government of the person but by the international community is the international protection. According to a generally accepted view, the international protection begins with the substitute protection and it ends with a durable solution for the protected person.

* Yrd. Doç. Dr. Anadolu Üniversitesi Hukuk Fakültesi Milletlerarası Özel Hukuk ABD Öğretim Üyesi, E-mail: maygun@ anadolu.edu.tr.

**Ar. Gör. Anadolu Üniversitesi Hukuk Fakültesi Milletlerarası Özel Hukuk ABD Öğretim Elemanı, E-mail: cansu_k@anadolu.edu.tr.
} 
In international law, the three accepted methods aiming to supply a durable solution to the persons within the international protection are voluntary repatriation, resettlement and local integration. With local integration, the person is integrated to the society by according her many rights that are also accorded to citizens. By this way the status of the person in society is normalized. With coming in the force of The Foreigners and International Protection Law in 2014, the integration issue has held the first time in the Turkish Law. Legal regulations in the international law on the integration of the refugees and legal regulations in the Turkish Law on the integration of the refugees are the subjects of this study.

Keywords: Foreigners and International Protection Law, international protection, refugee law, local integration, social rights, nationality.

\section{GíRIŞ̧}

2011 yılı Mart ayı itibariyle Suriye'deki iç karışıklıklardan dolayı Türkiye'ye yoğun kitle akını yaşanmaya başlamıştır ve devam etmektedir. 2014 yılında, Avrupa Birliği (AB) iltica sistemi ile uyumlu olmayı amaç edinerek yürürlüğe giren Yabancılar ve Uluslararası Koruma Kanunu $\left(\mathrm{YUKK}^{1}{ }^{1}\right.$ ile birlikte, bu kişiler, geçici koruma uygulaması kapsamında ülkemizde bulunmaktadır. Geçici koruma ile ilgili, 2001/55/EC sayılı AB Konseyi Geçici Koruma Direktifinin dördüncü maddesinde, geçici koruma rejiminin geçiciliği vurgulanmaktadır. Düzenlemeye göre, geçici korumanın süresi bir yıl olup, altı aylık periyodlarla en fazla iki kere uzatılabilmekte ve dolayısıyla geçici koruma süresi en çok 2 yıl olabilmektedir. $^{2} 2014$ tarihinde yürürlüğe giren Geçici Koruma Yönetmeliğinde $^{3}$ ise, geçici koruma süresine ilişkin herhangi bir süre belirtilmemekte ancak 10. maddede Bakanlar Kurulu kararınca süre belirlenebileceği düzenlenmiştir. 2011 yılından bu yana ülkemizde bulunan Suriyelilerin geçici koruma kapsamında olmaları bu sebeple düşündürücüdür. Ayrıca, yapılan araştırmalarda, Türkiye'de bulunan Suriyelilerin önemli bir kısmının, Suriye'de karışıklıklar sona erse bile, bir daha dönmeyecekleri sonucu ortaya çıkmaktadır.

${ }^{1}$ Kanunun, 122. maddesi, 123. maddesinin birinci, ikinci, beşinci ve yedinci fikraları ile 124. maddesi hariç olmak üzere Beşinci Kısmı yayımı tarihinde; diğer hükümleri 11 Nisan 2014 tarihinde yürürlüğe girmiştir: RG. 11.04.2013-28615.

2 T.C. İçişleri Bakanlığı Göç İdaresi Genel Müdürlüğü, Avrupa Birliğinde Geçici Koruma Sayfasi. http://www.goc.gov.tr/icerik3/avrupa-birliginde-gecici-koruma_409_558_1096 (Erişim Tarihi: 10.03.2016).

${ }^{3}$ RG. 22.10.2014-29153. 
Ülkede sayıları milyonları geçen yeni bir nüfusun görmezden gelinmesi olanaksızdır. Bu sebeple, Suriye'den gelen kişilerin, Birleşmiş Milletler Mülteci Yüksek Komiserliği (BMMYK) tarafından genel kabul görmüş, gönüllü geri dönüş, üçüncü ülkeye yerleştirilme veya yerel entegrasyon çözümünden birine kavuşturulması gerekir. YUKK kapsamında bu kişiler, Avrupa dışından gelmiş kişiler olarak şartlı mülteci statüsünü elde edemediklerinden, üçüncü ülkeye yerleştirilme imkânları yoktur. Ayrıca, ülkelerindeki iç karışıklık devam ettiği için gönüllü olarak ülkelerine de geri dönememektedirler. Bu sebeple, bu kişilerin birçoğu için en uygun kalıcı çözüm olană̆ı, yerel entegrasyon olarak görülmektedir.

Çalışmada öncelikle, ilgili kişilerin, menşe ülkelerinin ulusal korumasından yararlanamadıkları için başka ülkelerden sağladıkları uluslararası koruma ve konu ile ilgili uluslararası hukuktaki düzenlenmeler anlatılacaktır. Uluslararası korumanın hukuki temeli anlatılırken, doğrudan mülteci hukuku ile ilgili belgeler ve herkes için olan insan hakları ile ilgili belgeler ayrı başlıklar altında açıklanacaktır. Konu ile ilgili olması bakımından insancil hukuk ve ceza hukukuna da değinilecektir. İlk bölümde uluslararası korumanın hukuki temeli anlatıldıktan sonra, doktrinde geleneksel olarak benimsenmiş üç kalıcı çözüm türü ve tarihsel gelişimi anlatılacaktır.

Çalışmanın ikinci kısmında yerel entegrasyonun gelişimi ve kapsamı anlatılacaktır. Yerel entegrasyon çözümü kapsamını, Hathaway'in ifadesiyle, içinden vatandaşlığın kazanılmasını çıkarttığımızda, kişiye sosyal hakların tanınması olarak açıklandığında ${ }^{4}$, entegrasyonu da açıklarken sosyal hakları ve uluslararası hukukta düzenlenme şekilleri ele alınacaktır. Çalışmayı fazla uzun tutmamak amacıyla, entegrasyon kapsamında kabul edilen tüm haklar değil; barınma hakkı, eğitim hakkı, çalışma hakkı ve vatandaşlığın kazanılması üzerinde durulacaktır.

Son kısımda da, YUKK ve Uygulama Yönetmeliği ${ }^{5}$ ile mevzuata dâhil olan uyum düzenlemesi üzerinde durulup, topluma entegre olmay1 sağlayacak bazı haklar üzerinde durulacaktır. Haklar hakkında açıklama yapılırken, konuya ilişkin var olan yönetmeliklere de değinilecektir. Söz

${ }^{4}$ James C. Hathaway, The Rights Of Refugees Under International Law, (Cambridge University Press, 2005), s. 978.

${ }^{5}$ RG. 17.03.2016-29656. 
konusu uyum düzenlemesi genel olarak yabancilar için getirilmiş olsa da, çalışmada söz konusu madde ve diğer haklar, sadece uluslararası koruma kapsamındaki kişiler ve geçici koruma kapsamındaki kişiler bakımından incelenecektir.

16 Aralık 2013 tarihinde Türkiye ile AB arasında Geri Kabul Anlaşması imzalanmış ve Haziran 2014 tarihinde Türkiye Büyük Millet Meclisi (TBMM) tarafından onaylanmıştır. Avrupa Komisyonunun, Avrupa Parlamentosu ve $A B$ Konseyine tavsiye niteliği taşıyan ve 5 bloktan oluşan Birinci Değerlendirme Raporunun bir bloğu "Göç Yönetimi"ne ayrılmıştır. ${ }^{6}$ Söz konusu bloklarda yer alan kriterlerde, Aralık 2013 tarihinde başlatılan diyalog sürecinden bugüne, Türkiye tarafindan söz konusu teknik kriterlerin karşılanması yönünde atılan adımlar değerlendirilmiş ve kriterlere uyumun artırılmasına yönelik hedef odaklı politika önerileri yer almıştır. Çalışmada yeri geldikçe, bu hususlara da yer verilecektir.

Çalışma, ulaştığımız vargıları içeren sonuç kısmı ile sona erecektir.

\section{ULUSLARARASI KORUMA HUKUKU VE KALICI ÇÖZÜMLER}

\section{A) Uluslararası Koruma Hakkında Genel Bilgiler}

\section{Uluslararası Korumanın Tanımı}

Uluslararas1 korumanın tanımına herhangi bir sözleşmeden ulaşılamamaktadır. Uluslararası korumanın tanımı her ne kadar yapılmamış olsa da, doktrinde genel kabul gören tanıma göre uluslararası koruma, kişiye kendi ülkesinin sağlamadığı korumanın, uluslararası alanda başka bir devlet tarafindan sağlanması olarak ifade edilmektedir. ${ }^{7}$ Uluslararası koruma, bireyin tâbiiyetinde olduğu devletten beklediği korumaya erişemediği anda devreye girer. ${ }^{8}$ BMMYK'nın 2006 yılında

${ }^{6}$ İktisadi Kalkınma Vakfı, Türkiye ile Vize Serbestliğine İlişkin Yol Haritast- Birinci Değerlendirme Raporu Analizi, (IKVV, 2014).

7 Tevfik Odman, Mülteci Hukuku, (Ankara: İmaj Yayınevi, 1995), s. 20-21; Bülent Çiçekli, Yabancılar ve Mülteci Hukuku, (Ankara: Seçkin Yayınevi, 2014), s. 221; Işı1 Özkan, Göç, İltica Ve Sığınma Hukuku, (Ankara: Seçkin Yayınevi 2013), s. 275; Neva Övünç Öztürk, Mültecinin Hukuki Statüsünün Belirlenmesi, (Ankara: Seçkin Yayıncılık 2015), s. 27.

${ }^{8}$ E. Feller, V. Türk ve F. Nicholson, (Der.), UNHCR's Global Consultations On International Protection, Refugee Protection In International Law, (Cambridge: Cambridge University Press, 2003), s. 336; Ann Vibeke Eggli, Mass Refugee Influx And 
yayımladığı "Master Glossary of Term" kitapçığında, uluslararası koruma şu şekilde tanımlanmıştır: Kişinin kendi ülkesinde sağlanamayan ulusal koruma yoksunluğundan dolayı, menşe ülkesi dışında temel haklarının korunmasını amaçlayan, temeli uluslararası hukuka dayanan, uluslararası toplum tarafından sağlanan korumadır. ${ }^{9}$

\section{Uluslararası Korumaya İlişkin Düzenlemeler}

a) Uluslararası Düzenlemeler

Uluslararası hukukun bağlayıcı kaynakları, Uluslararası Adalet Divanı Statüsünün 38. maddesi birinci fikrasında sayılmıştır. Bunlar, uluslararası anlaşmalar, uluslararası teamül hukuku kuralları ve çağdaş milletlerce kabul edilen hukukun genel prensipleri ve yardımc kaynak olarak da, uluslararası mahkeme içtihatları ve doktrindir. ${ }^{10}$

Mültecinin uluslararası alanda korunmasının hukuki temelini uluslararası insan hakları hukuku, uluslararası mülteci hukuku ve bazı durumlarda uluslararası insancıl hukuk ile uluslararası ceza hukuku oluşturur; adı geçen hukuk alanların kapsamını evrensel ve bölgesel anlaşmalar, uluslararası örf adet hukuku, hukukun genel ilkeleri ile yargı kararları ve doktrin oluşturur. ${ }^{11}$

\section{i. Uluslararası Mülteci Hukuku \\ Uluslararası Anlaşmalar}

Uluslararası mülteci hukuku alanında uluslararası nitelikte en önemli iki belge 1951 tarihli Mülteci Sözleşmesi ile 1967 tarihli Mülteci Protokolüdür. Kişinin, yaşam veya özgürlüklerinin ırk, din, tabiiyet, belirli bir sosyal gruba mensubiyet veya siyasi düşünceleri sebebiyle tehdit altında olabileceği ülkeye gönderilmesini yasaklayan geri gönderilmeme

The Limits Of Public International Law, (Hollanda: Martinus Nijhoff Publishers 2002), s. 14.

${ }^{9}$ United Nations High Commissioner for Refugees (UNHCR); Department of International Protection (DIP); Protection Information Section (PIS), UNHCR Master Glossary of Terms, Rev.1, June 2006, s. 13. http://www.refworld.org/docid/42ce7d444.html (Erişim Tarihi: 14.02.2016).

10 Birleşmiş Milletler, Birleşmiş Milletler Antlaşması ve Uluslararası Adalet Divanı Statüsü, s. 74. http://www.unicankara.org.tr/doc_pdf/adalet_divani.pdf (Erişim Tarihi: 03.03.2016).

${ }^{11}$ Office of the United Nations High Commissioner for Refugees, An Introduction to International Protection Protecting persons of concern to UNHCR Self-study module 1, (Geneva: UNHCR, 2005), s. 25; Çiçekli, s. 226-227. 
(non-refoulement) ilkesi de uluslararası korumanın temel taşlarındandır ${ }^{12}$ ve bu ilke 1951 tarihli Mülteci Sözleşmesi'nin 33. maddesi ilk fikrasında düzenlenmiştir. İlkenin uygulanmayacağı istisna haller ise aynı maddenin ikinci fikrasında düzenlenmiştir ve buna göre, kişinin, bulunduğu ülkenin güvenliği için tehlikeli olduğuna dair ciddi şüpheler varsa veya özellikle ciddi bir suçtan dolayı kesinleşmiş bir hükümle mahkûm olup o ülkenin halkı için tehlike teşkil etmesi söz konusuysa, bu ilkeden faydalanamaz. 1951 tarihli Mülteci Sözleşmesinin 33. maddesi aynı zamanda sınırdaki sığınmacıya, ayrıca ülkede bulunup henüz statüsü belirlenmemiş kişiye de uygulanır. ${ }^{13}$

\section{Bölgesel Anlaşmalar}

1969 tarihli Afrika Mülteci Sorunları Afrika Birliği Örgütü Sözleşmesi (ABÖ Sözleşmesi), şu an adı Afrika Birliği olan topluluğun üyeleri tarafından kabul edilmiştir. ${ }^{14} \mathrm{Bu}$ bölgesel Sözleşme, geniş mülteci tanımı, sığınma sağlanması konusunda devletlere getirdiği pozitif yükümlülük, kalıcı çözümlere yönelik teminat sağlanması ve mülteciler tarafindan yıkıcı faaliyetlerin yasaklanması ile ilgili düzenlemeler getirmesi sebebiyle, bölgesel olarak 1951 Sözleşmesinin tamamlayıcısı olmuştur. ${ }^{15}$

Avrupa Birliğine üye devletler, özellikle 1980 yılından sonra, sığınma politikalarını ve uygulamalarını uyumlu hale getirme kararı almışlar ve bu amaçla 1999 yılından itibaren, 1951 tarihli Mülteci Sözleşmesinin ortak uygulanması için Avrupa Ortak Sığınma Sistemini

12 Elif Uzun, "Geri Göndermeme (Non-Refoulement) İlkesinin Uluslararası Hukuktaki Konumu Üzerine Bir Değerlendirme", Uluslararası Hukuk ve Politika, Cilt: 8, Sayı:30, 2012, ss.25-58, s. 25; (UNHCR (2005), s. 26. Sığınmacı ve mültecilerin sınırdış1 edilmeleri ile ilgili olarak bkz.: Nuray Ekşi, "İnsan Hakları Avrupa Mahkemesi Kararlarında Sı ğınmacı Ve Mültecilerin Türkiye'den Sınırdışı Edilmelerini Engelleyen Haller", İstanbul Barosu Dergisi, Cilt: 82, Say1: 6, 2008, s. 2801-2838; Gökhan Taneri, Uluslararası Hukukta Mülteci ve Siğınmacıların Geri Gönderilmemesi (NonRefoulement) Illkesi, (Ankara: Bilge Yayınevi, 2012).

${ }^{13}$ UNHCR (2005), s. 26.

${ }^{14} 1969$ tarihli ABÖ Mülteci Sözleşmesi 20 Haziran 1974 tarihinde yürürlüğe girmiştir: Mehmet Özcan, Avrupa Birliği Siğınma Hukuku, (Ankara: USAK Yayınları, 2005), s. 19.

${ }^{15}$ Odman (1995), s. 49; UNHCR (2005), s. 27; Özkan, s. 167-168. 
kurmaya amaçlamışlardır. ${ }^{16}$ Avrupa Ortak Sı̆̆ınma Sistemi kısaca şu düzenlemeleri kapsamaktadır ${ }^{17}$ :

- Geçici koruma düzenlemesi (2001 tarihli Geçici Korumaya İlişkin Konsey Yönergesi) ${ }^{18}$,

- Sığınmacıların ülkeye alınması için asgari şartların düzenlenmesi (2003 tarihli Siğınma İsteyenlerin Ülkeye Kabulüne İlişkin Asgari Standartların Belirlenmesine İlişkin Konsey Yönergesi) ${ }^{19}$,

- Sığınma talebini incelemek üzere sorumlu üye devletin belirlenmesi için yeni bir düzenleme yapılması (2004 tarihli Sığınma Başvurusunun İncelenmesinden Sorumlu Devletin Belirlenmesine İlişkin Konsey Tüzüğü-Dublin II Tüzüğü),

- Sığınma talebinde bulunanların parmak izlerinin karşılaştırılabileceği yeni bir sistem oluşturulması (2003 Ocak ayından itibaren EURODAC olarak bilinen uygulama) ${ }^{20}$,

- Uluslararası koruma ihtiyacı olanları belirlemek için asgari standartları benimseyen "Vasıf" Yönergesinin düzenlenmesi (2011 Tarihli Mülteci ve İkincil Koruma Statüsüne İlişkin Standartlar Konusunda Parlamento ve Konsey YönergesiVasıf Yönergesi),

- Statü belirleme prosedürü için gerekli asgari ortak standartları tanımlayan Usul Yönergesinin düzenlenmesi (2013 tarihli Uluslararası Koruma Statüsünün Tanınması ve Geri Çekilmesi Konusunda Ortak Usullere İlişkin Parlamento ve Konsey Yönergesi- Ortak Usul Yönergesi).

Asgari usul normları getiren bu hükümlerin onaylanması, Avrupa Ortak Sığınma Sistemi kurulmasının ilk aşamasıdır; ikinci aşama ise, benimsenen ilkelerin devletler tarafindan milli hukuka dönüştürülmesi ve üye ülkeler arasında uygulama uyumunun sağlanmasıdır. ${ }^{21}$

${ }^{16}$ UNHCR (2005), s. 28; Özkan, s. 198-199; Avrupa Birliği'nde sığınma sisteminin gelişimi için bkz.: Nurcan Özgür ve Yeşim Özer, Türkiye'de sığınma sisteminin Avrupalılaştırılması, (İstanbul: Derin Yayınları, 2010), s. 7-96.

${ }^{17}$ UNHCR (2005), s. 28; Çiçekli, s. 229-230.

${ }^{18}$ Detaylı bilgi için bkz.: Özcan, s. 160-169.

19 Özcan, s. 178.

${ }^{20}$ Sistem şu anda Danimarka hariç tüm $\mathrm{AB}$ ülkeleri ve EURODAC düzenlemesine taraf olan Norveç ve İzlanda'da uygulanmaktadır: Özcan, s. 174.

${ }^{21}$ UNHCR (2005), s. 28. 
1984 tarihli mültecilerle ilgili Cartagena Bildirgesi, Orta Amerika'yı etkileyen iç savaş sonrası doğan mülteci krizine çözüm bulmak için hükümet temsilcileri, bölgeden akademisyen ve avukatların da katılımıla kabul edilen belgedir. ${ }^{22}$ Tipk1 Afrika Organizasyonu Mülteci Sözleşmesi gibi, bu Belge de 1951 tarihli Mülteci Sözleşmesinin tamamlayıcısı olmasının yanı sıra, mülteciler için insani muamele ve kalıcı çözümler sağlanması konusunda öneriler ortaya koymaktadır. ${ }^{23}$

\section{Uluslararası Teamül Hukuku}

Geri Gönderme Yasağı (Non-refoulement), uluslararası örf ve adet hukukunun bir parçasıdır. ${ }^{24}$ Bu sebeple tüm ülkeler, herhangi bir kişinin, siyasi düşünce veya sosyal bir gruba mensubiyet, milliyet, din, 1rk1 sebebiyle özgürlüğü veya hayatının tehdit edileceği bölge veya ülkeye gönderilmesine ilişkin yasakla bağlıdır. Bu bağlılık, söz konusu ilkeye uygun davranma yükümlülügünün 1951 tarihli Mülteci Sözleşmesi veya 1967 tarihli Mülteci Protokolüne taraf olmayan ülkeleri de bağlaması sebebiyle önemlidir.

\section{Yargı Kararları ve Doktrin}

Hukuk, yapısı sebebiyle yoruma açıktır. Uluslararası alanda, aynı konuya dair ortak bir anlayışı kurabilmek için, devletlerin hukuki sorunlar karşısında üst mahkemelerinin kararlarını incelemek önemlidir. ${ }^{25}$ Ülkelerin, uluslararası mülteci hukukundan doğan yükümlülüklerinin yerine getirilmesinin denetlenmesinde, mahkemelerin görüşleri, uluslararası mülteci hukukunun içeriğinin belirlenmesi açısından önemlidir. ${ }^{26}$ Uluslararası mülteci hukuku alanında önde gelen akademisyenlerin görüşleri de, uluslararası korumanın yapısının belirlenmesinde yardımcı olur.

Mahkemeler, devletlerin mültecilere karşı yasal yükümlülüklerini incelerken sıklıkla BMMYK'nın Yürütücü Kurul Kararlarına, BMMYK'nın mülteci statüsünün belirlenmesinde usul ve kriterlere dair El

${ }^{22}$ Odman (1995), s. 52; Özkan, s. 169.

${ }^{23}$ Odman (1995), s. 53-54; Özkan, s. 170.

${ }^{24}$ UNHCR (2005), s. 28, 33; Çiğdem Altınışık ve Mehmet Şahin Yıldırım, Mülteci Haklarının Korunması (Ankara: Ankara Barosu Yayınları, 2002), s. 111; Çiçekli, s. 230; Acer, Kaya ve Gümüş, s. 34. Ayrıca, geri göndermeme ilkesinin, uluslararası örf ve adet hukuku kuralı veya bir jus cogens kural olup olmadığ 1 konusundaki tartışmalar için bkz.: Uzun, s. 26-58.

${ }^{25}$ UNHCR (2005), s. 29.

${ }^{26}$ UNHCR (2005), s. 29; Çiçekli, s. 230. 
Kitabına, BMMYK Koruma Rehberi gibi "soft law" araçlarına da atıf yapar. ${ }^{27}$ Soft Law, devletler tarafindan oluşturulmuş yasal dokümanlardan ziyade politik araçlardır ve bu sebeple yasal olarak bağlayıcı değillerdir, ancak devletlerin bakış açılarını sunmaları bakımından önemlidirler. ${ }^{28}$ Soft Law alanına dair evrensel nitelikte bildirgelerden bazıları şunlardır: Ülkesel Sığınma Bildirgesi $(1967)^{29}, 1951$ Sözleşmesi veya 1967 Protokolüne Taraf Devletler Bildirgesi $(2001)^{30}$ ve uluslararas1 koruma hakkında Yürütücü Komite (ExCom) Kararlar1 ${ }^{31}$.

\section{ii. Uluslararası İnsan Hakları Hukuku}

Uluslararası insan hakları hukuku, özellikle savunmasız insan grupları için insanca muamelenin tesisini amaçlaması ve her bireyin onur ve refahını korumaya odaklanması sebebiyle uluslararası mülteci hukukuyla yakından ilişkilidir. ${ }^{32}$ Uluslararası insan hakları hukuku, sığınma ülkesinde, uluslararası insan hakları hukukundan doğan mülteci ve sığınmacının sahip olduğu haklar açısından önemli olduğu gibi, mülteci adına ve onlar tarafindan kullanılabilen insan haklarının düzgün uygulanmasını denetleyen uluslararası mekanizmaları işletmesi açısından da önemlidir. ${ }^{33}$

İnsan hakları hukuku ayrım gözetmeksizin herkese uygulandığından, sığınmacının statüsüne bakılmaksızın, bulunduğu ülke topraklarında kendilerine yapılan muamelenin denetlenebilmesi ve herhangi bir mülteci sözleșmesine taraf olmayan devletlerin sorumlu tutulabilmesi bakımından önemlidir. ${ }^{34}$ Dolayısıyla, 1951 Sözleşmesi veya 1967 Protokolü kapsamında ulaşılamayan uluslararası şikâyet mekanizmalarına, birçok uluslararası insan hakları belgesi kapsamında, herkes gibi mültecilerin de başvurma hakkı vardır. ${ }^{35}$

\section{Uluslararası Anlașmalar}

İnsan haklar1 konusunda, uluslararası alanda insan haklarının temelini oluşturan belge, 1948 tarihli İnsan Hakları Evrensel

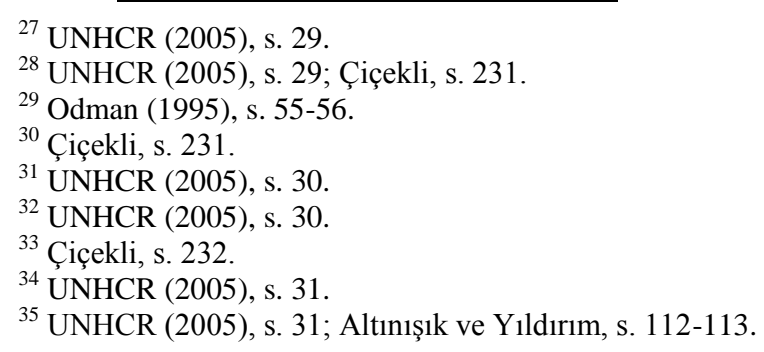


Beyannamesidir. ${ }^{36}$ İkinci Dünya Savaşının ardından kabul edilen bu belge, insan topluluğunun tüm üyelerinin temel özgürlüklerine ve onuruna saygıyı amaçlamaktadır. Beyanname, bildiri olarak yayınlanması nedeniyle, tanıyan devletlere herhangi bir yükümlülük getirmemekte ise de; kabul edildiğinden bu yana birçok kuralı yasal olarak bağlayıcı olan anlaşmalarla yinelenmiştir, teamül hukuku kuralı haline gelmiştir. ${ }^{37}$ Sözleşmenin tüm maddeleri, ayırt etmeksizin tüm insanlara tanınmış olmasına rağmen, 14. maddesinde "Herkes zulümden kaçıp başka ülkelere katılma ya da sığınma arama hakkına sahiptir." denilerek, sığınma talebi hakkına vurgu yapılmıştır. ${ }^{38}$

1966 y1lında kabul edilen ve "İkiz Sözleşmeler" şeklinde anılan, Ekonomik, Sosyal ve Kültürel Haklar Sözleşmesi ile Medeni ve Siyasal Haklar Sözleşmesi, Evrensel Beyannamede yer alan hak ve özgürlükleri daha kapsamlı düzenlemektedir. ${ }^{39}$ Medeni ve Siyasi Haklar Uluslararası Sözleşmesinin 4. madde ikinci fikrasında, yaşam hakkı, işkence ya da zalimane, insanlık dışı ya da aşağılayıcı muamele ya da cezaya maruz kalmama hakkı sıralanmıştır ve bu haklar her durumda ve her zaman korunmalıdırlar, bu haklar ihlal edilemez (non-derogable) haklar olarak adlandırılırlar. ${ }^{40} \mathrm{Bu}$ Sözleşmenin taşıdığı en önemli özelliklerden birisi, sözleşmeci devletlerin Sözleşmede yer alan insan haklarına saygı gösterip göstermediğini denetlemek üzere, yaptıkları çalışma ve aldıkları tedbirleri belli aralıklarla BM Genel Sekreterliği aracılığıyla İnsan Hakları

3610 Aralık 1948 tarihinde imzalanan Beyanname, 27 Mayıs 1949 tarihli 7217 sayılı Resmi Gazete'de yayınlanmıştır: Rona Aybay, Açıklamalı İnsan Hakları Evrensel Bildirisi, Türkiye $\quad$ Barolar $\quad$ Birliği $\quad$ Yayınları http://tbbyayinlari.barobirlik.org.tr/TBBBooks/insan_haklari_evrensel_bildirisi.pdf (Erişim Tarihi: 13.02.2016).

${ }^{37}$ UNHCR (2005), s. 32; Altınışık ve Yıldırım, s. 140; Özkan, s. 57.

${ }^{38}$ Sı ̆̆ınma arama hakkının, talep etme hakkı veya sığınmayı kabul hakkı olup olmadığına dair tartışmalar için bkz.: Neva Övünç Öztürk, "Avrupa Birliği Temel Haklar Şartında Yer Alan Sığınma Hakkının Tahlili” İnönü Üniversitesi Hukuk Fakültesi Dergisi, Cilt:3 Say1:2, 2012; Özkan, s. 57.

39 Türkiye, Medeni ve Siyasal Haklar Sözleşmesi'ni 21.07.2003 tarih ve 25175 sayılı Resmi Gazete'de yayınlanan kararla ve Ekonomik, Sosyal ve Kültürel Haklar Sözleşmesini'ni ise 11.08.2003 tarih ve 25196 sayılı Resmi Gazete'de yayımlanan karar ile onamıştır. Rona Aybay, İnsan Haklarl Hukuku (İstanbul: İstanbul Bilgi Üniversitesi Yayınlar1, 2015), s.44-45.

${ }^{40}$ UNHCR (2005), s. 33. 
Komitesine bildirme yükümlülüğü getirmesidir. ${ }^{41}$ Aynı denetim şekli diğer Sözleşme için de, gelişmelerin dönemsel olarak Ekonomik ve Sosyal Konseye (BMESK) bildirilmesi şeklinde olmaktadır. ${ }^{42}$

Uluslararası alanda kabul edilmiş diğer anlaşmalardan bazıları şunlardır: Irk Ayrımının Her Türlüsünün Önlenmesine ilişkin Uluslararası Sözleşme $(1965)^{43}$, Kadına Karşı Ayrımcılığın Her Türlüsünün Önlenmesine İliş̧kin Birleşmiş Milletler Anlaşması (1979) ${ }^{44}$, Birleşmiş Milletler İşkence, Diğer Zalimane, İnsanlık Dışı ya da Küçük Düşürücü Muamele ve Cezaya Karşı Sözleşme (1984) ${ }^{45}$, Birleşmiş Milletler Çocuk Hakları Sözleşmesi (1989) ${ }^{46}$, Tüm Göçmen İşçilerin ve Aile Fertlerinin Haklarının Korunmasına Dair Uluslararası Sözleşme (1990) ${ }^{47}$.

\section{Bölgesel Anlaşmalar}

İnsan hakları hukukunun gelişiminde bölgesel anlaşmalar da önemli bir yer tutar. Avrupa İnsan Hakları Sözleşmesi (1950) ${ }^{48} 49$, Avrupa Sosyal Şartı (1961), Afrika Halklar ve İnsan Bildirgesi (1981) bölgesel anlaşmalardan birkaçıdır. Diğer bölgesel anlaşmalara örnek olarak 1985 Inter-Amerika Sözleşmesi (1985), Avrupa Konvansiyonu (1987), Afrika Çocuk Hakları Bildirgesi (1990), Gözden Geçirilmiş Avrupa Sosyal Şartı $(1996)^{50}$ gelmektedir.

${ }^{41}$ Hüseyin Pazarc1, Uluslararası Hukuk Dersleri II. Kitap. (3. Bas1), (Ankara: Turhan Kitabevi, 1993), s. 194-196; Altınışık ve Yıldırım, s. 141.

${ }^{42}$ Pazarcı, s. 196; Altınışık ve Yıldırım, s. 142.

${ }^{43}$ RG. 16.06.2002-24787.

${ }^{44}$ RG. $14.10 .1985-18898$.

${ }^{45}$ RG. 10.08.1988-19895.

${ }^{46}$ RG. 27.01.1995-22184.

${ }^{47}$ RG. 08.07.2004-25516.

${ }^{48}$ RG. 19.03.1954-8662.

49 Sözleşmenin en önemli özelliklerinden birisi, denetim mekanizması olarak, hem bireysel, hem de devlet başvurularını kabul etmesi ve başvuru hakkının devlet tarafından kullanılabilmesi için ayrıca bir kabule gerek yokken; bireysel başvuru için devletlerin ilgili maddeyi kabulünün şart olmasıdır. Türkiye, 1954 yılında AİHS'ye taraf olmuş, 1987'de Sözleşmeye bağlı Komisyonuna bireysel başvuru hakkını kabul etmiş, 1990 yılında da Avrupa Adalet Divanının yargı yetkisini tanımıştır. Altınışık ve Yıldırım, s. $142-143$.

${ }^{50} 1961$ yılında kabul edilen Avrupa Sosyal Şartı güncellenerek yeni halini almıştır. Türkiye Şartı 2004 tarihinde kabul etmişse de, Şart ülkemizde 2007 tarihinde yürürlüğe girmiştir. 


\section{İnsan Hakları Başvuru Mekanizmaları}

Yukarıda açıklanan anlaşmaların kabulüyle birlikte, bu anlaşmaların uygulanmasını denetlemek ve insan hakları ihlali iddialarını incelemek için çeşitli kurumlar oluşturulmuştur. Birleşmiş Milletler bünyesinde, her biri ayrı yapılanmaya sahip insan haklarının korunmasını gözlemlemek için oluşturulmuş birçok kurum vardır. Bu kuruluşlar ya BMESK tarafindan veya bazı evrensel insan hakları anlaşmaları sonucunda kurulmuşturlar ve her kuruluş türü de evrensel nitelik taşır. ${ }^{51}$ BMESK tarafindan kurulan iki kurum İnsan Hakları Komisyonu ve Kadın Statüsü Komisyonudur. ${ }^{52}$

\section{iii. Uluslararası İnsancıl Hukuk}

İnsancıl hukuk, savaş veya silahlı çatışma durumlarında, insanların korunması ve savaş araçlarının sınırlandırılmasını amaçlayan hukuk dalıdır. ${ }^{53}$ Hem insan hakları hukuku hem de mülteci hukukundan daha önceye dayanan uluslararası hukukun bu dalının amacı, silahlı çatışmalar süresince, hiç düşmanca faaliyette bulunmamış ya da artık bulunmayan kişileri korumak, savaş yöntemi ve araçlarını kısıtlayıp düzenlemektir. ${ }^{54}$ Bu alandaki önemli belgeler, Cenevre Sözleşmeleri (1949) ${ }^{55}$ ve onun iki Ek Protokolleri (1977) ile üçüncü Protokoldür (2005). ${ }^{56}$

\section{iv. Uluslararası Ceza Hukuku}

Çok sayıda mülteci, güvenli bir yer bulabilmek umuduyla ülkesinden kaçarken kaçakçılara güvenmek durumunda kalır. Ancak

${ }^{51}$ UNHCR (2005), s. 34.

${ }^{52}$ UNHCR (2005), s. 35. Sözleşmeler sonucunda kurulmuş kurumlar ise şunlardır: İnsan Hakları Komisyonu (Kişisel ve Siyasi Haklar Sözleşmesi), İşkenceye Karşı Komite (BM İşkence Sözleşmesi), Ekonomik, Sosyal ve Kültürel Haklar Komisyonu (Uluslararas1 Ekonomik, Sosyal ve Kültürel Haklar Sözleşmesi), Irk Ayrımının Azaltılması Komisyonu (BM Irk Ayrımı Sözleşmesi), Kadına Karşı Ayrımcılığın Önlenmesi Komisyonu (BM Kadın Sözleşmesi), Çocuk Hakları Komisyonu (BM Çocuk Hakları Sözleşmesi), Göçmen İşçi ve Aile Üyeleri Haklarının Korunması Komisyonu ( Göçmen Sözleşmesi). Bölgesel sözleşmeler sonucunda kurulmuş olan kurumlar ise şunlardır: Avrupa İnsan Hakları Mahkemesi (Avrupa İnsan Hakları Sözleşmesi), Inter-Amerikan İnsan Hakları Mahkemesi ve Komisyonu, Afrika İnsan ve Halklar Mahkemesi ve Komisyonu, Avrupa İşkencenin Önlenmesi Komisyonu.

${ }^{53}$ Ayşe Nur Tütüncü, İnsancıl Hukuka Giriş, (İstanbul: Beta Yayınevi, 2006), s. 1.

${ }^{54}$ UNHCR ,(2005), s. 36; Özkan, s. 35; Gökhan Güneysu, Çevrenin Silahlı Çatışmalar Esnasında Korunması, (Ankara: Adalet Yayınevi, 2014), s. 21; Melike Batur Yamaner, Silahlı Çatışmalarda Sivillerin Korunması, (İstanbul: Arıkan Yayınevi, 2007), s. 19-21.

${ }^{55}$ RG. 30.01.1953-8322.

56 Türkiye Protokollere taraf değildir. 
kaçakçılara güvenip güvenli ülke arayışına çıkan sığınmacı, sadece kendi hayatını değil, aynı zamanda varacağı ülkede sığınma bahşedilmesi ihtimalini de tehlikeye atar. Mültecilerin, kaçakçılar tarafından suiistimal edilmesini önleme amaçlı iki belge, 2004 yılında yürürlüğe giren Birleşmiş Milletler Göçmenlerin Havada, Karada ve Denizde Kaçakçılığına Karşı Protokolü (2000) ve 2003 yılında yürürlüğe giren Birleşmiş Milletler İnsan Ticaretini Yasaklama ve Önleme Protokolüdür. ${ }^{57}$

\section{b) Yabancilar ve Uluslararası Koruma Kanunu (YUKK)}

1951 tarihli Mültecilerin Hukuki Durumuna Dair Cenevre Sözleşmesi ve 1967 tarihli Mültecilerin Hukuki Statüsüne İlişkin Protokol, Türk hukukunda uluslararası koruma hukukunun temel belgeleridir. Türkiye, Sözleşmeye katılırken, "1 Ocak 1951'den Avrupa'da cereyan eden hadiseler" ibaresi ile mülteci tanımına coğrafi ve tarihi sınırlama koymuştur. ${ }^{58}$ Daha sonra 1967 Protokolünü imzalayarak tarih sınırlamasına son vermiştir fakat coğrafi sınırlama hala geçerliliğini korumaktadır.

Türk hukukunda uzun yıllar 1951 Sözleşmesi ve Protokolü dışında, mültecilerle ilgili kanun düzeyinde bir yasal bir düzenleme bulunmamaktayd1. ${ }^{59} 1994$ tarihli "ïltica ve Sığınma Yönetmeliği”" ile mülteci hukukuna ilişkin işlemler yapılmaktaydı. Çoğu idarenin eylem ve işlemlerine dayanan sığınma hukukuna ilişkin uygulamaların temelini kanundan almaması, hem ülke içinde hem de ülke dışında eleştirilere yol açmaktaydı. Bu sebeple Avrupa Birliğine adaylık sürecinde yer alan Türkiye, $\mathrm{AB}$ müktesebatı ve uygulamalarına uyum çalışmaları çerçevesinde sığınma ile ilgili mevzuatını yenileme yoluna gitmiştir. ${ }^{60}$

${ }^{57}$ UNHCR, (2005), s. 38.

${ }^{58}$ Odman, (1995), s. 165.

${ }^{59} 1994$ Yönetmeliği yürürlüğe girene kadar mülteci hukukuna dair Türkiye'deki uygulamalar hakkında bilgi için bkz.: Kemal Kirişçi, Türkiye "Coğrafi Sinırlama"yı Kaldırıyor Mu? (Ankara: Sı ğınmacı ve Göçmenlerle Dayanışma Derneği, 1996), s. 2-8; Özgür ve Özer, s. 109-128; Acer, Kaya ve Gümüş, s. 63-72; Mürvet Ece Büyükçalık, Mülteci Hukukunun Gelişimi ve Türkiye'de Mültecilerin Sosyal Haklart, (İstanbul: On İki Levha Yayıncılık 2015), s. 63-90.

${ }^{60}$ Öztürk (2015), s. 378; Büyükçalık, s. 111-114. AB müktesebatının üstlenilmesine ilişkin Türkiye Ulusal Programında göç ve iltica alanındaki başlıca taahhütler için bkz.: Nuray Ekşi, Yabancılar Ve Uluslararası Koruma Hukuku, (3. Bas1), (İstanbul: Beta Yayınevi, 2015a), s. 17-24. Sığınma alanında Avrupalılaşmanın yasal ve kurumsal çerçevesi için bkz.: Özgür ve Özer, s. 132-148. 
2014 yılında yürürlüğe giren YUKK ile birlikte, mülteciler ve uluslararası koruma kapsamındaki diğer kişilere ilişkin konuları kanun seviyesinde düzenlemeye tabi tutmaktadır. Kanuna göre, mülteciler, şartlı mülteciler ve ikincil koruma talep eden yabancilar uluslararası koruma statüsünden yararlanabilirler. Kanunun 61. maddesine göre, mülteci, Avrupa ülkelerinde meydana gelen olaylar nedeniyle; 1rk1, dini, tabiiyeti, belli bir toplumsal gruba mensubiyeti veya siyasi düşüncelerinden dolayı zulme uğrayacağından haklı sebeplerle korkan kişidir. Şartlı mülteci, Avrupa ülkeleri dışında meydana gelen olaylar sebebiyle, aynı nedenlerle haklı zulüm korkusu yaşayan kişidir. Üçüncü ülkeye yerleştirilinceye kadar, şartlı mültecinin Türkiye'de kalmasına izin verilir (m. 62). İkincil koruma statüsü ise, mülteci veya şartlı mülteci statüsü elde edemeyecek, ancak menşe ülkesine geri gönderildiği takdirde; ölüm cezasına mahkûm olacak veya ölüm cezası infaz edilecek (m. 63/1), işkenceye, insanlık dış1 ya da onur kırıcı ceza veya muameleye maruz kalacak (m. 63/1-b), uluslararası veya ülke genelindeki silahlı çatışma durumlarında, ayrım gözetmeyecek şiddet hareketleri nedeniyle şahsına yönelik ciddi tehditle karşılaşacak olması sebebiyle (m. 63/1-c) menşe ülkesi veya ikamet ülkesinin korumasından yararlanamayan veya yararlanmak istemeyen yabancı veya vatansız kişilere sağlanır.

YUKK ile Türk hukukunda ilk kez yasal düzenlemeye konu olan geçici koruma statüsü 91. maddede düzenlenmiştir. Ülkesinden zorla ayrılan ve geri dönemeyen, acil ve geçici koruma bulmak amaciyla, kitlesel olarak sınırlarımıza gelen veya sınırlarımızı geçen yabancılara sağlanacak koruma, geçici koruma olarak adlandırılmaktadır. 2011 yılından itibaren kitlesel akınla Türkiye'ye gelen Suriyelilerin statüsü, geçici koruma statüsüdür. ${ }^{61}$

\section{B) Kalıcı Çözümler ve Tarihi Gelişimi}

BMMYK belgesine göre, uluslararası koruma, kişinin sığınma ülkesine girişi, kendisine sığınma bağışlanması, temel insan haklarına sayg1, güvenliğinin tehdit edildiği ülkeye geri gönderilmemesi (nonrefoulement) ile başlar; kendisine kalıcı çözümün sağlanması ile sona erer. $^{62}$

${ }^{61}$ Nuray Ekşi, "Suriyelilere Toplu Olarak Türk Vatandaşlığı Verilebilir Mi?”, İstanbul Barosu Dergisi, Cilt: 89, Say1:2, Y11: 2015b, s. 196-202, s. 196.

${ }^{62}$ UNHCR (2005), s. 7. 
Bireyin yoksun kaldığı ulusal korumanın ikamesi olan uluslararası koruma, ancak mültecinin kalıcı çözüme ulaşması ile sona erer. ${ }^{63}$ Mültecilerin yerinden edilme döngüsüne son vererek, normal hayatlarına devam edebilmelerini sağlayacak çözüm yolları, kalıcı çözüm (durable solution) olarak adlandırılmaktadır ${ }^{64}$ Geleneksel olarak benimsenmiş üç kalıcı çözüm türü şunlardır ${ }^{65}$ :

- Gönüllü geri dönüş (voluntary repatriation), kişilerin kendi istekleriyle, menşe ülkelerine geri dönebilmeleri ve ulusal korumadan tekrar faydalanmalarıdır.

- Yerel entegrasyon (local integration), kişilerin, hukuki, sosyal, ekonomik ve kültürel boyutlarda, bulundukları ülkeye entegre olmalarını sağlayan kademeli bir süreçtir.

- Yeniden yerleştirme (resettlement), kişinin, üçüncü bir ülkeye yeniden yerleştirilmesidir.

Geçmişte, bu üç kalıcı çözüm türü arasında, gönüllü geri dönüş çözüm türünün öncelikli görüldüğü bir hiyerarşi söz konusuydu ve birçok sığınmacı, şartlar oluşur oluşmaz ülkelerine dönmek için istekliyken, sığınmanın sağlandığı ev sahibi ülke de bu çözüm türünü desteklemekteydi. ${ }^{66}$ Geçmişte, gönüllü geri dönüş daha fazla ön plana çıkmışken, günümüzde bu üç çözüm türünün birbirini tamamlayıcı olduğu kabul edilmektedir. ${ }^{67}$ Bunun anlamı, devletler bu üç kalıcı çözüm

${ }^{63}$ Eggli, s. 16; UNHCR (2003), s. 6.

${ }^{64}$ UNHCR (2005), s. 137; Çiçekli, s. 355.

${ }^{65}$ Öztürk (2015), s. 33-34.

${ }^{66}$ BMMYK küresel danışma yazısında ev sahibi ülkenin gönülsüz tutumuna gerekçe olarak, kendi nüfusunun ihtiyaçlarını karşılamakta zorlanan ev sahibi ülkenin, yoğun mülteci nüfusunun olumsuz çevresel ve ekonomik etkileri hakkında kaygıları; ev sahibi ülkenin, uluslararası camianın yeterli yük paylaşımında bulunmayacağı inancıyla, çok sayıda mülteci nüfusunu barındırmakta gönülsüzlügü; sürgün nüfusun ev sahibi ülkenin milli güvenliğine tehdit oluşturabileceği inancı ve devletin uluslararası sınırları üzerinde nüfus hareketlerini kontrol yeteneğini kaybetme korkusu gösterilmektedir. UN High Commissioner for Refugees (UNHCR), Global Consultations on International Protection/Third Track: Local Integration, 25 April 2002a, EC/GC/02/6, s. 4. http://www.refworld.org/docid/3d6266e17.html (Erişim Tarihi: 12.02.2016).

${ }^{67}$ Üç çözüm türünün birbirini tamamlayıcı nitelikte olduğunu söyleyen belgeler için bkz.: UNHCR (2002a), s. 5-6, http://www.refworld.org/docid/3d6266e17.html (Erişim Tarihi: 12.02.2016); UN High Commissioner for Refugees (UNHCR), Global Consultations on International Protection/Third Track: Strengthening and Expanding Resettlement Today: Dilemmas, Challenges and Opportunities, 25 April 2002b, EC/GC/02/7, s. 7, 
türünden yalnızca biri üzerinde odaklanmamalı, aksine her durumun özelliğine göre, o duruma en uygun olan çözüm türü izlenmelidir. İç savaşların uzun yıllar sürmesi sebebiyle ülkesine dönemeyen ve iç güvenlik endişeleri sebebiyle başka bir ülkeye de kabul edilmeyen kişilerin varlığı, gönüllü geri dönüş veya yeniden yerleştirme çözüm türlerinin uygulanmasını kimi zaman olanaksız kılmaktadır. Böyle bir durumda, menşe ülkesine geri dönemeyen mülteci için, yerel entegrasyon çözüm yolu tercih edilir. ${ }^{68}$

BMMYK bünyesinde yerel entegrasyon çözümü 2000'li y1llardan sonra daha çok önem kazanmıştır. Özellikle 2003 yılında yayımlanan Koruma Rehberi ${ }^{69}$ ve Kalıcı Çözümler Sistemi ${ }^{70}$ belgeleri ile ülkeler arasında yük paylaşımı ve kalıcı çözümler üzerinde odaklanılmıştır. Koruma Rehberi, kalıcı çözümlerin sağlanması için, mültecinin kendi ihtiyaçlarını karşılayacak duruma gelmesini teşvik edici çözüm olanakları sunarken, aynı zamanda, kalıcı çözüm olarak yerel entegrasyonun önemine de vurgu yapmaktadır. ${ }^{71}$ Kalıcı Çözümler Sistemi belgesi de kalıcı çözümlerin gerçekleştirilmesine yönelik el kitabı olarak yayınlanmıştır. ${ }^{72} \mathrm{Bu}$ belgede de yine mültecilerin kendi kendine yetebilmesi, hükümetler arası işbirliğinin artması, kitlesel mülteci hareketlerine daha etkili çözüm bulmak amacıyla insani yardımların artırılmasının önemine vurgu yapılmaktadır.

\section{KALICI ÇÖZÜM TÜRÜ OLARAK YEREL ENTEGRASYON \\ A) Yerel Entegrasyon Kavramı ve Gelişimi}

Mültecilere yönelik üç kalıcı çözüm türünden biri olan yerel entegrasyon, mültecinin sığındığı ülkede sürekli kalacağı ve sıkıntılı

http://www.refworld.org/docid/3d62679e4.html (Erişim Tarihi: 12.02.2016); Çiçekli, s. 357-358.

${ }^{68}$ Rosa da Costa, Rights Of Refugees In The Context Of Integration: Legal Standards And Recommendations, Legal and Protection Policy Research Series, (Geneva: UNHCR, 2006), s. 11. http://www.unhcr.org/44bb90882.pdf (Erişim Tarihi: 12.02.2016).

${ }^{69}$ UNHCR, Agenda For Protection (3. Basim). UNHCR, 2003b http://www.unhcr.org/3e637b194.html (Erişim Tarihi: 16.02.2016).

${ }^{70}$ UNHCR Core Group on Durable Solutions, Framework for Durable Solutions for Refugees and Persons of Concern,(Geneva: UNHCR, 2003a) http://www.refworld.org/docid/4124b6a04.html (Erişim Tarihi: 16.02.2016).

${ }^{71}$ UNHCR (2003b), s. 73-81.

${ }^{72}$ Bkz. dn. 70. 
durumlarına bu ülkede çözüm sağlanacağı varsayımına dayanır. Hukuki, ekonomik ve sosyokültürel süreçten oluşan yerel entegrasyon çözümü, yerel yerleşim (local settlement) ${ }^{73}$ ve kendi kendine yetebilme (self reliance $)^{74}$ kavramlarından farklıdır. ${ }^{75}$

BMMYK belgelerinde yapılan tanıma göre yerel entegrasyon, çok yönlü ve süreklilik arz eden bir sürecin sonucudur. Entegrasyon, mültecilerin kendi kültürel kimliklerini terk etmek zorunda kalmadan, ev sahibi ülkeye uyum sağlama sürecidir ve birbiriyle bağlantılı ve kendine has ayrımları olan, yasal, ekonomik ve sosyokültürel boyuttan oluşur. ${ }^{76}$ $\mathrm{Bu}$ tanımda geçen "kendi kültürel kimliklerini terk etmek zorunda kalmadan ifadesi", entegrasyonun asimilasyon kavramından ayrılması bakımından önemlidir.

$\mathrm{Bu}$ çalışmada, mülteci sorununa kalıcı çözüm bulmaya yönelik yerel entegrasyon sürecinin yalnızca hukuki boyutu ele alınacaktır. Söz konusu hukuki sürecin tamamlanması, aynı zamanda başarılı bir entegrasyonun diğer boyutlarının gerçekleşmesi için de önkoşul niteliği taşımaktadır.

BMMYK belgelerinde yerel entegrasyonun yasal süreci, mültecilere, ev sahibi ülke tarafından aşamalı olarak, kendi vatandaşlarına orantılı şekilde geniş hak ve yetkilerin tanınması olarak tarif edilmektedir.

${ }^{73}$ UNHCR'nin Handbook for Self- Reliance kitabında açıklandığ 1 üzere, self reliance yani kişinin kendi kendine yetebilmesi kavramı yerel entegrasyon çözüm türünden farklı bir kavramdır. Kendi kendine yetebilme, bireyin sosyal ve ekonomik olarak kendi yaşamını idame ettirebilmesidir. Kişinin yiyecek, su, barınma, kişisel güvenlik ve eğitim gibi temel ihtiyaçlarını sürekli ve insan onuruna yakışır bir şekilde karşılayabileceği koşulların oluşmasıdır. Kendi kendine yetebilirlik, kişinin yaşamını idame ettirmesini kolaylaştıracağı gibi, uzun vadede, dışarıdan sürekli yardım alma ihtiyacını da azaltır. Kendi kendine yetebilme, mültecinin üç kalıcı çözümden birine erişeceğini garanti etmez, ancak, herhangi bir kalıcı çözüme erişim sürecinde, aşamalı sürecin bir parçasını oluşturur. UNHCR, Handbook For Self-Reliance, (Geneva: UNHCR, 2005a), s. 1. http://www.unhcr.org/44bf7b012.pdf (Erişim Tarihi: 11.02.2016).

${ }^{74}$ Yerel yerleşim (local settlement) kavramı ile yerel entegrasyon kavramı kimi zaman hatalı bir şekilde birbirinin yerine kullanılmaktadır. Bu iki kavram çoğu zaman birbirinin yerine kullanılsa da, birbirinden farklı iki kavramdır. Yerel yerleşim, yerel entegrasyon ve kendi kendine yetebilme arasında bir anlama sahiptir. UNHCR (2002a), s. 4. http://www.refworld.org/docid/3d6266e17.html (Erişim Tarihi: 11.02.2016).

${ }^{75}$ Çiçekli, s. 358.

${ }^{76}$ UNHCR (2002a), s. 2, http://www.refworld.org/docid/3d6266e17.html (Erişim Tarihi: 12.02.2016); Yücel Acer, İbrahim Kaya ve Mahir Gümüş, Türkiye'nin Illtica Stratejisi, (Ankara: USAK Yayınları, 2010), s. 17-18. 
Serbest dolaşım ve seyahat özgürlüğü, eğitim ve öğretim hakkı, iş piyasasına erişim, sağlık hizmetlerini de kapsayan sosyal yardım hakkı, mülkiyet hakkı, geçerli seyahat ve kimlik belgeleri ile seyahat etme imkânı ve aile birliğinin sağlanması, yerel entegrasyon sürecinin hukuki boyutunun tamamlanması için tanınması gerekli haklar olarak sayılmaktadır. ${ }^{77} \mathrm{Bu}$ süreç çoğu zaman, daimi ikamet hakkına erişim ve devamında vatandaşlığın kazanılmasını ile sonuçlanmaktadır.

\section{B) Entegrasyonu Sağlamada Bazı Temel Haklar ve Yasal Düzenlemeler}

\section{Entegrasyon Hakkı}

Konu ile ilgili temel düzenleme 1951 Sözleşmesi 34. maddede ve BMMYK Statüsü ikinci paragrafta yer almaktadır. Sözleşmenin 34. maddesine göre, "Âkit Devletler, mültecileri imtisal eyleme (özümleme) ve vatandaşlı̆̆a almayı her türlü imkân nispetinde kolaylaştırtrlar. Vatandaşlı̆̆a alma muamelelerini çabuklaştırmaya ve bu muamelenin masraf ve resimlerini her türlü imkân nispetinde azaltmaya bilhassa gayret ederler. "78

Sözleşmenin orijinal halinde, 34. maddede mültecilerin sığındıkları ülkede "asimilasyon"u (assimilation) ifadesi kullanılmıştır. Başlangıçta tartışmalara yol açan bu ifadenin mültecinin asimilasyonu veya üzerinde bask1 uygulanması anlamında kullanılmadığı, aksine, ülkenin sosyal, ekonomik ve kültürel hayatına entegre olması şeklinde anlaşılması gerektiği konusunda doktrinde fikir birliği sağlanmıştır. ${ }^{79}$ Uluslararası camia da, söz konusu ifadenin, mültecinin, ev sahibi ülkenin milletinden ayırt edilemez olacak şekilde kendi kültür ve yaşam tarzını terk edeceği beklenmesi fikrini çoktan reddetmiştir. ${ }^{80} \mathrm{Bu}$ sebeple asimilasyon terimi yerine daha çok entegrasyon terimi tercih edilmektedir.

34. maddenin devletlere biri genel, diğeri de özel iki yükümlülük getirdiği kabul edilmektedir; genel yükümlülük olarak devletlerden

\footnotetext{
${ }^{77}$ Hathaway, s. 978; UNHCR (2002a), s. 2, http://www.refworld.org/docid/3d6266e17.html (Erişim Tarihi: 12.02.2016).

${ }^{78}$ RG. 5.09.1961-10898.

79 Nehemiah Robinson, Convention Relating To The Status Of Refugees: Its History, Contents And Interpretation, (Geneva: UNHCR, 1997), s. 64. http://www.unhcr.org/3d4ab67f4.pdf (Erişim Tarihi: 17.02.2016); UNHCR (2002a), s. 2, dipnot 3. http://www.refworld.org/docid/3d6266e17.html (Erişim Tarihi: 17.02.2016).

${ }^{80}$ UNHCR (2002a), s. 2, dipnot 3. http://www.refworld.org/docid/3d6266e17.html (Erişim Tarihi: 17.02.2016).
} 
beklenen, mültecilerin ev sahibi topluma özümsenmeleri ve vatandaşlığa alınma imkânının sağlanması iken, daha özel olarak, vatandaşlı̆̆a alınma işlemlerini hızlandırılması ve bu sürecin masraflarını en aza indirecek her türlü çabanın gösterilmesidir. ${ }^{81}$

Mülteciler, diğer yabancıların aksine, dönebilecekleri menşe ülkeye sahip değillerdir; dolayısıyla sığındıkları ülkeden başka güvenecekleri bir yetkili de yoktur. Bu sebeple, ev sahibi ülke, bu kişilerin ülkeye entegrasyonu ve haklarının tanınması için çaba göstermelidirler. ${ }^{82} 34$. madde de bu bağlamda, mültecilerin özel durumları sebebiyle, kendilerine hakların tanınması ve diğer yabancılar için alınan önlemlerin ötesinde ve kendi vatandaşlarına veya kalıcı ikamet sahibi olanlara tanıdığı hakların tanınması konusunda taraf devletleri yükümlü kılmaktadır. ${ }^{83}$

1951 Sözleşmesinin yanında, BMMYK Tüzüğü de, Komiserliğin görevlerinden birisinin, statüsü tanınmış mültecilerin entegrasyonunda gerek devletlere gerekse özel organizasyonlara yardım ederek mülteci korumasının sağlanması olduğunu söylemektedir. ${ }^{84}$ Statü özellikle, vatandaşlı̆̆ın kazanılmasının kolaylaştırılarak entegrasyonun artırılması için ülkelere çağrıda bulunmaktadır. ${ }^{85}$

Bölgesel düzenlemelere bakıldığında, Avrupa Birliği Bakanlar Konseyinin 2004 yılında çıkarttığı ve Birliğin Üye Devletlerini bağlayan Yönergesi (Avrupa Konsey Yönergesi) de entegrasyon hakkı kavramına açıkça vurgu yapan belge olarak gösterilebilir. Yönergenin 33. maddesine göre:

"1. Mültecilerin topluma entegrasyonunu kolaylaştırmak amaciyla Üye Devletler uygun gördükleri entegrasyon programlarını sağlayacaklar ya da bu programlardan yararlanmayı temin eden ön koşulları oluşturacaklardır.

${ }^{81}$ Robinson, s. 64. http://www.unhcr.org/3d4ab67f4.pdf (Erişim Tarihi: 17.02.2016); Atle Grahl-Madsen, Commentary on the Refugee Convention 1951, Division of International Protection, (Geneva: UNHCR, 1997), s. 144-148.

${ }^{82}$ Costa, s. 25.

${ }^{83}$ Costa, s. 25.

${ }^{84}$ Statute of the Office of the United Nations High Commissioner for Refugees, General Assembly Resolution 428 (V) of 14 December 1950, s. 4. http://www.unhcr.org/3b66c39e1.html (Erişim Tarihi: 19.02.2016); Odman (1995), s. 32; Özkan, s. 133; Çiçekli, s. 356; Acer, Kaya ve Gümüş, s. 31.

${ }^{85}$ Statute, s. 4. http://www.unhcr.org/3b66c39e1.html (Erişim Tarihi: 19.02.2016); Acer, Kaya ve Gümüş, s. 49. 
2. Üye Devletlerin uygun bulduklarl durumlarda, ikincil koruma statüsünden yararlanan kişilerin entegrasyon programlarından yararlanmalarina olanak taninacaktır. ",86

Madde, üye devletlere, mültecilerin topluma entegrasyonunun kolaylaştırılmasını söylemekte ancak bu bağlamda neler yapılabileceği konusunda, devletlere "uygun görecekleri entegrasyon programın sağlayacaklardır" diyerek bu hususu açık bırakmaktadır. Ancak gerek Yönergenin giriş kısmında üçüncü cümlede Cenevre Sözleşmesi ve Protokolünün mülteci hukukunda esası oluşturduğunu kabul etmesi, gerekse sekizinci cümlede daha elverişli hükümlerin konması konusunda üye devletlerin yetkili k1lınması, gerekse 20. maddesi ilk cümlesinde, Cenevre Sözleşmesinde tanınan hakların saklı tutulması, bu açıklığın mülteci lehine giderileceğini ortaya koymaktadır. ${ }^{87}$

1951 Sözleşmesinde tanınan haklar, hem Cartagena Deklarasyonu hem de Afrika Birliği Örgütü (ABÖ) Sözleşmesinde desteklenmektedir. ABÖ Sözleşmesi önsöz dokuzuncu paragrafta, 1951 Sözleşmesi ve Protokolünün mültecilerin statüsüne ilişkin temel ve evrensel belgeyi oluşturduğu yazmaktadır. ${ }^{88}$ Cartegena Deklarasyonu 6. maddede, "mültecilere săglanan güvenliğin arttırılmasını, insan haklarının güvence altına alınmasinı ve kendi kendine yeterliliklerinin arttırllması ve ev sahibi toplumla entegrasyonlarını hedefleyen projelerin uygulanmasinı göz önüne almayl" nihai karar olarak benimsemektedir. ${ }^{89} \mathrm{Bu}$ ifade ile hem entegrasyona hem de mültecilerin kendi kendilerine yetebilmesine ( reliance) vurgu yapmaktadır. Yine 11. maddede "Çok sayıda mülteci bulunan bölgedeki ülkelerde, uluslararası topluluk tarafindan BMMYK

${ }^{86}$ BMMYK Türkiye ve Türk İçişleri Bakanlığı, İltica ve Göç Mevzuatı, (Ankara: Başkent Matbaas1 2005), s. 224. http://www.goc.gov.tr/files/files/iltica_goc.pdf (Erişim Tarihi: 19.02.2016). Maddenin orijinal metnine http://www.unhcr.org/43661eee2.pdf adresinden ulaşılabilir. Bu maddenin devamında BMMYK'nın maddeye ilişsin yorumu da yer almaktadir.

${ }^{87}$ İltica ve Göç Mevzuatı, s. 209- 220. http://www.goc.gov.tr/files/files/iltica_goc.pdf (Erişim Tarihi: 19.02.2016).

88 Organization of African Unity (OAU), Convention Governing the Specific Aspects of Refugee Problems in Africa ("OAU Convention"), 10 September 1969, 1001 U.N.T.S. 45 http://www.refworld.org/docid/3ae6b36018.html (Erişim Tarihi: 19.02.2016).

${ }^{89} 1984 \quad$ Cartagena Mülteciler Bildirisi, http://sorular.rightsagenda.org/Uploads/MULTECI\%20MEV/1984\%20CARTAGENA\% 20M\%C3\%9CLTEC\%C4\%B0LER\%20B\%C4\%B0LD\%C4\%B0R\%C4\%B0S\%C4\%B0. pdf (Erişim Tarihi: 19.02.2016). 
vasitasiyla sunulan kaynakları istihdam yaratılmasina ya da oluşturulmasına ayırarak, bu kişileri ülkenin üretici yaşamına entegre etmek ve böylece mültecilerin ekonomik, sosyal ve kültürel haklarından yararlanmaları konusunda gereken çalışmayı yapmak" ${ }^{\prime 90}$ benimsenen nihai kararlar arasında sayılmaktadır.

\section{Yasal İkamet ve Barınma Hakkı}

Yasal ikamet hakkı konusunda ne uluslararası ne de bölgesel hukuki metinlerde açık bir düzenleme yoktur. Bu durumun tek istisnası, Avrupa Konsey Yönergesidir. Yönergenin 24. maddesine göre, statüsü tanınan mülteci ve aile üyelerine, ulusal güvenlik ve kamu düzeni aksini gerektirmediği müddetçe, en az üç yıl geçerli ve yenilenebilir ikamet izni verilir. ${ }^{91}$ Yine 2003/109/AT Direktifine göre, ilgililer, gerekli belgeleri göstererek ve üye ülkede beş yıl hukuka uygun ve devamlı ikamet ettiklerini ispat ederek, uzun süreli ikamet iznini elde edebilirler. ${ }^{92} 11$ Nisan 2011 tarihinde, söz konusu Direktifte değişiklik yapılarak, ikincil korumadan yararlananlar ile mülteciler, beş yıldan fazla bir süredir yasal olarak $\mathrm{AB}$ 'de yaşayan diğer üçüncü dünya ülkeleri vatandaşları ile benzer şartlarda uzun dönem ikamet izni verilen kişi statüsü alacakları düzenlenmiştir. ${ }^{93}$ Uzun dönem ikamet statüsü verilen ve uluslararas1 korumadan yararlananlar uzun dönem ikamet statüsü bulunan diğer bütün üçüncü dünya ülkesi vatandaşları gibi, $\mathrm{AB}$ içerisinde serbest dolaşım hakkı ve özellikle de başka bir $A B$ ülkesinde ikamet edebilme hakkını, ikamet ettikleri AB ülkesi vatandaşları ile belirli şartlar altında, eğitim, işgücü piyasasına erişim ve sosyal sigorta hakları gibi çok çeşitli

${ }^{90} 1984 \quad$ Cartagena Mülteciler Bildirisi, http://sorular.rightsagenda.org/Uploads/MULTECI\%20MEV/1984\%20CARTAGENA\% 20M\%C3\%9CLTEC\%C4\%B0LER\%20B\%C4\%B0LD\%C4\%B0R\%C4\%B0S\%C4\%B0. pdf (Erişim Tarihi: 19.02.2016).

${ }^{91}$ İltica ve Göç Mevzuat1, s. 221. http://www.goc.gov.tr/files/files/iltica_goc.pdf (Erişim Tarihi: 19.02.2016).

92 Özkan, s. 214.

93 "Delegation of the European Union to Turkey" sitesinde yer alan habere göre, uzun dönem ikamet izni verilenlere ilişkin AB direktifi uluslararası korumadan yararlananlar ile mültecileri kapsayacak şekilde genişletilmiştir. http://www.avrupa.info.tr/tr/bilgikaynaklari/haber-arsivi/news-single-view/article/uzun-doenem-ikamet-izni-verilenlereiliskin-ab-direktifi-uluslararasi-korumadan-yararlananlar-ile.html (Erişim Tarihi: 20.02.2016). Söz konusu hükümler İngiltere, Danimarka ve İrlanda'da geçerli değildir. 
ekonomik ve sosyal konularda eşit muamele görme hakkına sahip olacaktır. $^{94}$

İkamet izni, birçok ülke hukukunda, başka hakların tanınabilmesi için varlı̆̆ gerekli şartlardan biri olduğundan, entegrasyon sürecinde ayr1 bir öneme sahiptir. Hatta çoğu ülkede, kişilerin vatandaşlığından ziyade ikamet iznine sahip olup olmadığı önem taşımaktadır. ${ }^{95}$ Dolayısıyla mülteciye ikamet izninin verilmesi, entegrasyon sürecinde diğer hakların verilmesini de kolaylaştıır. Bunun yanında, 1951 Sözleşmesi 34. maddede devletlerin yükümlülüklerinden birisi de, mültecilerin vatandaşlığa alınma sürecini kolaylaştırmaktır ve mülteciye verilmiş ikamet izni, vatandaşlığa alınma sürecinde kolaylık sağlamaktadır.

Barınma hakkı, 1951 Sözleşmesinde 21. maddede düzenlenmiştir. Maddeye göre, Taraf Devletler, konut edinme bakımından, ülkelerinde yasal olarak ikamet eden mültecilere, aynı şartlar altındaki yabancılara uygulanandan daha az olmayacak biçimde, mümkün olduğu kadar müsait bir muamele sağlayacaklardır. ${ }^{96}$

İnsan Hakları Evrensel Bildirgesinin 25. maddesinde herkesin barınma hakkının olduğu düzenlenmektedir. Ekonomik, Sosyal ve Kültürel Haklar Hakkında Sözleşmenin 11. maddesinde, Sözleşmeye taraf devletlerin, herkesin konut hakkını tanıdığı düzenlenmektedir.

Ekonomik, Sosyal ve Kültürel Haklar Komitesinin barınma hakkı adlı yorum belgesinde, bu hakkın dar ve sinırlandırıcı yorumlanmaması

${ }^{94}$ http://www.avrupa.info.tr/tr/bilgi-kaynaklari/haber-arsivi/news-single-view/article/uzundoenem-ikamet-izni-verilenlere-iliskin-ab-direktifi-uluslararasi-korumadanyararlananlar-ile.html (Erişim Tarihi: 20.02.2016).

${ }^{95}$ Costa, s. 42.

${ }^{96} 1951$ Sözleşmesinin 6. maddesine göre, ""aynı şartlarla" kavramı, belli bir kimsenin, söz konusu bir haktan yararlanabilmesi için, özellikleri açısından bir mültecinin yerine getiremeyecekleri dışında, mülteci olmasaydı belli bir hakkı kullanmak için yerine getirmesi gereken bütün şartları (geçici yahut daimi ikamet süresine ve şartlarına ait olanlar dâhil), kendisinin yerine getirmesi anlaminı ima eder." Bu durumda da yine mülteciden, mülteci olması sebebiyle gerçekleştiremeyeceği şartları sağlaması beklenemez. Burada aynı şartlardaki yabancılar ifadesinden anlaşılması gereken 1951 Sözleşmesi madde 6nın 1şı̆̆ında, belli bir kimsenin, söz konusu bir haktan yararlanabilmesi için, özellikleri açısından bir mültecinin yerine getiremeyecekleri dışında, mülteci olmasaydı belli bir hakkı kullanmak için yerine getirmesi gereken bütün şartları (geçici yahut daimi ikamet süresine ve şartlarına ait olanlar dâhil) kendisinin yerine getirmesidir. Konu ile ilgili değerlendirmeler için bkz.: Altınışık ve Yıldırım, s. 32; Özkan, s. 299-304. 
gerektiği, haktan anlaşılması gerekenin yalnızca kişinin başını sokacağı bir ev değil aynı zamanda güvenlik, barış ve onurlu bir yerde yaşama hakk1 olarak algılanması gerektiğine vurgu yapılmıştır. ${ }^{97}$

Uluslararası hukuk, kadın ve çocukların barınması ile ilgili özel düzenlemelere gitmiştir. Ekonomik, Sosyal ve Kültürel Hakların 11. maddesinde olduğu gibi, Kadınlara Karşı Her Türlü Ayrımcılığın Önlenmesi Uluslararası Sözleşmesi (CEDAW) 14. maddesinde, özellikle konut, sağlık, elektrik ve su temini, ulaştırma ve haberleşme konularında yeterli yaşam standartlarından yararlanma haklarını sağlamakla taraf devletleri yükümlü kılmaktadır. Çocuk Haklarına Dair Sözleşme 27. maddesinde, taraf devletlerin, gereksinim olduğu takdirde özellikle beslenme, giyim ve barınma konularında maddi yardım ve destek programları uygulayacağını düzenlemektedir. ${ }^{98}$ Her Türlü Irk Ayrımcılığının Tasfiye Edilmesine Dair Uluslararası Sözleşmesi 5. maddesinde, âkit devletlerin, özellikle konut hakkının (5/e-iii) kullanımında hukuk önünde eşitlik hakkını güvence altına almayı taahhüt etmektedir.

Göçmen İşçilere İlişkin 97 Sayılı Uluslararası Çalışma Teşkilatı Sözleşmesi (97 sayılı ILO Sözleşmesi) 6. maddesinde, Sözleşmenin yürürlükte bulunduğu her ülke için bu hükümler milliyet, 1 rk, din ya da cinsiyet ayırımı yapmaksızın, kendi vatandaşlarına uyguladıklarından daha aşağı olmayan bir muamelede bulunma yükümlülüğü getirmektedir ve barınma yerine ilişkin, yasal işlemler taraf devletlerce yapılır. ${ }^{99}$

Bölgesel düzeyde, konu ile ilgili Avrupa İnsan Hakları Mahkemesi ve Avrupa İnsan Hakları Komisyonunun birçok kararı vardır ve genellikle hâkim olan görüş, devletlerin vatandaşlarına konut sağlamakta yasal bir

${ }^{97}$ Committee on Economic, Social and Cultural Rights, General Comment 4, The right to adequate housing (Sixth session, 1991), U.N. Doc. E/1992/23, annex III at 114 (1991), reprinted in Compilation of General Comments and General Recommendations Adopted by Human Rights Treaty Bodies, U.N. Doc. HRI/GEN/1/Rev.6 at 18 (2003). Paragraf 7, https://www1.umn.edu/humanrts/gencomm/epcomm4.htm .

${ }^{98}$ Tevfik Odman, Çocuk Hakları Bağlamında Çocuk Mülteciler, (Ankara: Çağ Üniversitesi Hukuk Fakültesi Yayınları, 2008), s. 150.

${ }^{99}$ International Labour Organization, C097 - Migration for Employment Convention (Revised), 1949 (No. 97),

http://www.ilo.org/dyn/normlex/en/f?p=NORMLEXPUB:55:0::NO::P55_TYPE,P55_LA NG,P55_DOCUMENT,P55_NODE:CON,en,C097,\%2FDocument (Erişim Tarihi: 20.02.2016). Türkiye bu Sözleşmeye taraf değildir. 
zorunluluklarının olmadığı ancak yine de otoritelerin, kişinin yaşam koşullarını katlanılamaz şekilde dayatmaması gerektiğine de vurgu yapmaktadır. ${ }^{100}$

Avrupa İnsan Hakları Sözleşmesi Ek Protokolü ilk maddesinde her gerçek ve tüzel kişinin mal ve mülk dokunulmazlığına saygı gösterilmesini isteme hakk1 olduğu düzenlenmiştir. Sözleşmenin 8. maddesinde de, herkesin özel ve aile hayatına, konutuna ve yazışmasına sayg1 gösterilmesi hakkına sahip olduğu düzenlenmiştir.

Avrupa Birliğinde, Avrupa Konsey Yönergesi 31. maddesinde, üye devletlerin, mülteci ya da ikincil koruma statüsünden yararlanan kişilerin topraklarında yasal olarak ikamet eden üçüncü ülke vatandaşları ile eşit koşullar altında barınma olanaklarından yararlanmasını temin edecekleri düzenlenmiştir.

Amerika kıtasında bölgesel bir düzenleme olan San Salvador Protokolünde barınma konusuna ilişkin özel bir düzenleme söz konusu değildir.

\section{3. Çalışma Hakkı}

1951 Sözleşmesinin 17, 18 ve 19. maddeleri, mültecilerin çalışma hakkını düzenlemiştir. Bu maddeler, mültecilerin çalışma hakkını ücretli işte çalışanlar, kendi işinde çalışanlar ve uzmanlık alanında çalışanlar için, yabancı kişilerle aynı düzeyde güvence altına almıştır ve yabancılar için getirilen kısıtlamalar, mülteciler için de uygulanabilir. ${ }^{101}$

17. maddenin ilk fikrasına göre taraf devletler, aynı şartlar içinde yabancı bir memleketin vatandaşına uyguladıkları en müsait muameleyi uygulamakla yükümlüdürler.

Maddede geçen "aynı şartlar içinde" ifadesi, Sözleşmenin altıncı maddesindeki açıklama 1şığında, çalışma izninin elde edilebilmesi için diğer yabancıların sağlaması gereken, ikamet izni ve benzeri şartları sağlamasını gerektirir. ${ }^{102} \mathrm{Bu}$ durumda da yine mülteciden, mülteci olması sebebiyle gerçekleştiremeyeceği şartları sağlaması beklenemez.

Maddenin ikinci fikrasına göre, şu üç koşuldan birine sahip olan mülteciye ulusal işgücü piyasasını korumak amacıyla tedbir

${ }^{100}$ Costa, s. 70.

${ }^{101}$ Altınışı ve Yıldırım, s. 127; Costa, s. 49.

102 Bkz. dn. 95. 
uygulanmayacaktır: Ülkede üç y1l ikamet etmiş olmak ${ }^{103}$; ikamet ettiği ülkenin vatandaşı olan bir kimse ile evli bulunmak (eşini terk etmiş olan bir mülteci bu hükümden istifadeyi iddia edemeyebilir) ${ }^{104}$ ve ikamet ettiği ülkenin vatandaşlığını taşıyan bir veya daha fazla çocuğu olmak. ${ }^{105} \mathrm{Bu}$ koşullardan birini sağlayan mülteci için, ulusal işgücü piyasasını korumak amacıyla, yabancı kişiye uygulanabilecek kısitlayıcı tedbirler uygulanmayacaktır. Ancak kısıtlayıcı tedbirler, işgücü piyasasını korumak için değil de, memurluk mesleğinin sadece vatandaşlara mahsus olması gibi milli güvenlik endişesi sebebiyle getiriliyorsa, mülteci bu koşulları sağlasa da muafiyetten yararlanamayacaktır. ${ }^{106}$

Kendi işinde çalışmayı düzenleyen 18. madde, "Taraf devletler, ülkelerinde yasal olarak ikamet eden mültecilere tarım, sanayi, küçük sanatlar ile ticaret sahalarına kendi iş yerlerini açmak ve sanayi, ticari şirketler kurmak hakları ile ilgili olarak, mümkün olduğu kadar lehte ve her halde genel olarak aynı şartlardaki yabancılara uyguladiklarından daha az lehte olamayan muameleyi uygulayacaklardir."

Sözleşmenin 19. maddesinde de, "Her taraf devlet, ülkesinde yasal olarak ikamet eden ve bu devletin yetkili makamlarinca tanınan diplomalara sahip olup, bir ihtisas mesleğini icra etmek isteyen mültecilere, mümkün olduğu kadar lehte ve her halde aynı şartlar içindeki tüm yabancllara sağlanandan daha az lehte olmayan şekilde muamele uygulayacaktır.

Taraf devletler, bu gibi mültecilerin, anavatanları dışında, uluslararası iliş̧kilerini yürüttükleri ülkelere yerleşmelerini temin için, kanunlarına ve anayasalarına göre ellerinden gelen çabayı göstereceklerdir."

${ }^{103}$ Buradaki üç yıllık sürenin, kişinin mülteci olarak geçirip geçirmemesinin, yasal veya yasal olmayan şekilde bulunmasının önemli olmadığı ve fikranın olabildiğince özgürlükçü yorumlanması yönünde açıklamalar için bkz.: Grahl-Madsen, 43.

${ }^{104}$ Buradaki evli bulunmak ifadesinin de eşler ayrı yaşıyor olsa bile veya gerçek ve yasal bir boşanmaya rağmen maddi desteğin devam etmesi gibi durumların varlığı halinde bu fikranın uygulanabileceği yönünde açıklamalar için bkz.: Grahl-Madsen, 44.

${ }^{105} \mathrm{Bu}$ fikrada da çocuğun aile birliği içinde veya dışında doğmasının önemli olmadığı, çocuğun geçimini sağlayacak mülteci ebeveynin iş sahibi olmasında o ülkenin kamu yararının olduğu yönünde açıklamalar için bkz.: Grahl-Madsen, 44.

${ }^{106}$ Costa, 50 . 
Hem 18 hem de 19. madde, mültecilerin kendi işinde çalışmak veya bir ihtisas mesleği icra etmekte oldukları ülkede "mümkün olan en lehte muameleye" tabi tutulmalarını düzenlemektedir.

İnsan Hakları Evrensel Bildirgesi, 23. maddesinin ilk fikrasında, "Herkesin çalışma, işini özgürce seçme, adil ve elverişli çalışma koşullarına sahip olma ve işsizliğe karşı korunma hakkı vardır" hükmüne yer vermiştir. Ekonomik, Sosyal ve Kültürel Haklar Hakkında Sözleşmesi 6. maddesinde, Sözleşmeye taraf devletlerin, "herkesin özgürce seçeceği ve kabul edeceği bir işle yaşamını kazanma firsatına sahip olma hakkını içerecek şekilde çalışma hakkını tanıdığını ve bu hakkı güvence altına almak için uygun adımları atacağını" hüküm altına almıştır.

CEDAW 11. ve 14. maddesi ile Her Türlü Irk Ayrımcılığın Ortadan Kaldırılmasına İlişkin Uluslararası Sözleşme 5. maddesinde çalışma hayatında ayrımcılığa karşı koruma sağlamaktadır. Söz konusu uluslararası belgeler, çalışma hakkını herkese tanıdığı için, mültecilere de 1951 Sözleşmesinin sağladığından daha yüksek standartta hak tanımaktadır. ${ }^{107}$

Avrupa Birliği Konsey Yönergesinin 26. maddesi ilk fikrasında, üye devletlerin, kişiye mülteci statüsü verildikten hemen sonra mesleğe ve kamu hizmetine genel olarak uygulanan kurallara tabi olarak istihdam ya da serbest meslek faaliyetlerine girişebilmelerine izin verecekleri düzenlenmiştir. Ayrıca üye devletler, mültecilerin istihdamla ilgili eğitim firsatları, mesleki eğitim ve pratik işyeri deneyimi gibi etkinliklerinde kendi vatandaşlarıyla eşit koşullar sunacaklardır. ${ }^{108}$

Avrupa Birliği bağlamında mülteciler, Yönergeden bağımsız olarak, işçilerin serbest hareketi ve ırka dayalı ayrımcılığı yasaklayan düzenlemeler kapsamında değildir. 2003 yılında kabul edilen uzun dönemli ikamet eden üçüncü ülke vatandaşlarının durumu hakkında Konsey Yönergesinin 3. maddesinde, mülteci olan veya mülteci olarak kabul edilmek için başvurmuş olup başvurusu henüz kesin karar aşamasına gelmemiş olan kişilerin Yönerge kapsamında olmadığını düzenlemektedir. ${ }^{109} \mathrm{Bu}$ sebeple üye devletteki bir mülteci, Avrupa Birliği

${ }^{107}$ Costa, s. 51.

${ }^{108}$ İltica ve Göç Mevzuatı, s. 222. http://www.goc.gov.tr/files/files/iltica_goc.pdf (Erişim Tarihi: 20.02.2016).

${ }^{109}$ İltica ve Göç Mevzuat1, s. 182. http://www.goc.gov.tr/files/files/iltica_goc.pdf (Erişim

Tarihi: 20.02.2016). 
içerisinde, işçilerin serbest dolaşımı ve başka üye devlette istihdamının sağlanmasında Yönergenin kapsamından yararlanamayacaktır.

Amerika kıtasında, Amerika İnsan Hakları Sözleşmesi'nin 26. maddesinde ${ }^{110}$ ekonomik, sosyal ve kültürel haklar düzenlenmektedir ve bu madde taraf devletlere ekonomik alanda mevzuat çıkartılmasını, aşamalı olarak gelişmelerinin sağlanmasını ve önlemler alınmasını görev olarak söylemektedir. Bu Sözleşmeye ek Protokol olan Ekonomik, Sosyal ve Kültürel Haklar Alanında Amerikan İnsan Hakları Sözleşmesine Ek Protokol (San Salvador Protokolü) ${ }^{111}$ 6. maddesinde çalışma hakk1 ayrıntılı olarak, 3. maddede de ayrımcılık yasağı düzenlenmiştir.

\section{Eğitim Hakkı}

1951 Sözleşmesi 22. maddesinde, taraf devletlerin, temel eğitim konusunda vatandaşlara uyguladıkları muamelenin aynısını mültecilere de uygulayacakları düzenlenmiştir. Bu madde, özel eğitimin dışında, kamu tarafından finanse edilen eğitim olması sebebiyle önem taşır. ${ }^{112} \mathrm{Bu}$ maddenin taraf devletlerce uygulanabilmesi için, mültecinin, ülkede yasal ikametinin bulunmasına gerek yoktur ve bu sebeple sığınmacilar da bu maddeden faydalanacaklardır. ${ }^{113}$ Madde, çocukların ilköğretimlerinde, taraf devlet vatandaşlarıyla eşit muamele görmesini amaçlamaktadır. ${ }^{114}$

Temel eğitim dışındaki eğitim ise maddenin ikinci fikrasında düzenlenmiştir. Buna göre taraf devletler, yabancı ülkelerden alınmış eğitim sertifikalarının, üniversite diplomalarının ve derecelerinin tanınması konusunda, aynı şartlar altındaki ${ }^{115}$ yabancılara sağlanan imkânlardan daha az müsait olmayan şekilde muamele edeceklerdir. Burada temel ve yükseköğrenimin tanımı, imzacı devletlerin kendi hukuk

\footnotetext{
${ }^{110} 22$ Kasım 1969 'da kabul edilen Belge 18 Temmuz 1978'de yürürlüğe girmiştir. Sözleşmeye ek 2 protokol söz konusu olup, bunlardan ilki ekonomik, sosyal ve kültürel hak ve özgürlüklere ilişkin San Salvador Protokolü; diğeri ise ölüm cezasının kaldırılmasına ilişkin Paraguay protokolüdür. Volkan Aslan, "Amerikalılar Arası İnsan Hakları Sistemi”, İnönü Üniversitesi Hukuk Fakültesi Dergisi, Cilt:3 Sayı:2 Y11 2012, s. 268.

${ }^{111}$ Ekonomik, Sosyal ve Kültürel Haklar Alanında Amerikan İnsan Hakları Sözleşmesine Ek Protokol (San Salvador Protokolü) 17 Kasım 1988'de kabul edilmiş ve 16 Kasım 1999'da yürürlüğe girmiştir. Aslan, s. 269.

112 Robinson, s. 42; Özkan, s. 331.

${ }^{113}$ Costa, s. 80.

114 Özkan, s. 331.

${ }^{115}$ Bkz.: dn. 95.
} 
düzenlemelerine bağlıdır. ${ }^{116}$ Sözleşmenim 22. maddesine göre, eğitim sertifikalarının, üniversite diplomalarının ve derecelerinin tanınmasında, harç ve resimlerden muafiyet ayrıca düzenlenmiştir. Bununla birlikte, 29. madde genel olarak, taraf devletlerin, mültecilere, her ne isimle olursa olsun, benzer koşullarda vatandaşlarına uyguladıklarından veya uygulayabileceklerinden farklı ya da daha yüksek resim, harç ve vergi uygulamayacaklarını düzenlemiştir.

Eğitim hakkının diğer uluslararası veya bölgesel belgelerde düzenlenişine bakıldığında, 1951 Sözleşmesinden daha kapsamlı hükümlerin yer aldığı görülmektedir. Bu sözleşmelerin birçoğu eğitim hakkını sadece mülteciler için değil tüm çocuklar için güvence altına almaktadır. Ayrıca birçoğunun bünyesinde denetim mekanizmasının bulunması, hakların uygulanmasının takibini de sağlamaktadır.

İnsan Hakları Evrensel Bildirgesi 26. maddede, herkesin eğitim hakkına sahip olduğu, eğitimin en azından ilk ve temel aşamada ücretsiz ve ilköğretimin zorunlu olduğu düzenlenmiştir.

Ekonomik, Sosyal ve Kültürel Haklara İlişkin Uluslararas1 Sözleşme'nin 13. maddesine göre, Sözleşmeye taraf devletler, herkesin eğitim görme hakkına sahip olduğunu kabul ederler. Sözleşmenin ikinci fikrasına göre, taraf devletler, ilköğretimin herkes için zorunlu ve parasız olacağını kabul etmişlerdir. Medeni ve Siyasal Haklara İlişkin Uluslararası Sözleşmenin 26. maddesinde de, herkesin yasalar önünde eşit olduğunu ve devletlerin her bağlamda ayrımcılığa karşı eşit ve etkili korumayı temin edecekleri düzenlenmiştir.

Diğer uluslararası sözleşmeler arasında 143 No'lu ILO Sözleşmesinin 12. maddesinin $\mathrm{f}$ bendindeki, üye devletler kendi ülkesinin şartlarına uygun olarak göçmen işçi çocuklarına, ana dilbilgisi ve ülkeleri ile bağlarını korumak için tedbirler alınmasını düzenlemesi yer almaktadır. CEDAW'ın 10. maddesinde, taraf devletler eğitim alanında kadınların erkeklerle aynı haklara sahip olmalarını sağlamak için kadınlara karşı ayrımcılığı tasfiye etmek üzere gerekli her türlü tedbiri ve kadınlarla özellikle erkeklerin eşitliğine dayanan tedbirleri alacağını söylemekte ve devamında tedbirler konusunda örnekler vermektedir. Sözleşmenin 14. maddesi, kırsalda yaşayan kadının teknik bilgisinin

${ }^{116}$ Robinson, s. 43. 
artırılması için okuma yazma imkânlarının taraf devletlerce sağlanmasını düzenlemektedir.

Her Türlü Irk Ayrımcılı̆̆ının Tasfiye Edilmesine Dair Uluslararası Sözleşmenin 5. maddesinde, taraf devletlerin, eğitim hakkından yararlanmada herkesin kanun önünde eşitlik hakkını garanti altına almak yükümlülügünü üstleneceğini düzenlemektedir.

Amerikan İnsan Hakları Sözleşmesine Ek Protokol (San Salvador Protokolü) 13. maddesi de herkesin eğitim hakkına sahip olduğunu düzenlemekte ve devamında da, eğitim hakkının tam gerçekleşmesi için devletlere belli görevler yüklemektedir. Avrupa İnsan Hakları Sözleşmesi Ek Protokolü 2. maddesinde de eğitim hakkı düzenlenmiştir. Maddeye göre hiç kimse eğitim hakkından yoksun bırakılamaz. Devlet, eğitim ve öğretim alanında yükleneceği görevlerin yerine getirilmesinde, ana ve babanın bu eğitim ve öğretimin kendi dini ve felsefi inançlarına göre yapılmasını sağlama haklarına saygı gösterir.

Avrupa Birliğinde, Avrupa Konsey Yönergesi 27. maddesinde, üye devletlerin, mülteci ya da ikincil koruma statüsü verilen tüm küçüklere, eğitim sisteminden vatandaşlarıyla aynı koşullar altında yararlanabilmesine olanak tanıyacakları düzenlenmiştir. Üye devletler, yabancı diplomaların, sertifikaların ve diğer resmi vasıf belgelerinin mevcut tanınma usulü bağlamında, mülteci ya da ikincil koruma statüsünden yararlanan kişilere kendi vatandaşları ile eşit muamele gösterilmesini temin edeceklerdir.

\section{Vatandaşı̆ı̆ın Kazanılması}

Vatandaşlığın verilmesi, her devletin kendi münhasır yetkisi kapsamındadır. ${ }^{117}$ Ancak, konu mülteciler olduğunda, mülteci statüsünün sona ermesi ve ev sahibi ülkede entegrasyonun tam anlamiyla sağlanabilmesi için, uzun dönemde en tercih edilen statü kişiye vatandaşlığın verilmesidir. ${ }^{118}$ Her ne kadar mülteci statüsü kişiye belli bazı haklar sunsa da, etkili vatandaşlığın yokluğu, kişinin savunmasız olmasını devam ettirir. Çünkü bu süreçte mülteci geri gönderilmeme ve sığınma ülkesinde kalma hakkına sahip olsa bile, ne ülkesine dönebilmekte, ne de bulunduğu ülkede vatandaşlığın bahşettiği kapsamlı devlet korumasından yararlanmaktadır. ${ }^{119}$

117 Odman (1995), s. 176; Pazarc1, s. 60.

${ }^{118}$ Çiçekli, s. 379-380.

${ }^{119}$ Costa, s. 183. 
Vatandaşlığın kazanılması, hukuki açıdan, yeni bir toplum içine entegrasyon sürecinin tamamlanmasını ifade eder, söz konusu devletin yasal ve diplomatik koruma hakkı ile etkili bir vatandaşlık edinimini temsil eder. Her ne kadar 1951 Sözleşmesi 34. madde vatandaşlıkla sonuçlanacak bir yükümlülük içermiyor olsa da, hükmün ilk bölümü, vatandaşlığa ve entegrasyon (asimilasyon) sürecini kolaylaştırmak için gereken ihtiyaca vurgu yapar. ${ }^{120}$

Konuyla ilgili olarak, 1951 Sözleşmesinin 29. maddesini de tekrar düşünmek gerekir. 29. maddeye göre, taraf devletler, mültecilere, her ne isimle olursa olsun, benzer koşullarda vatandaşlara uyguladıklarından veya uygulayabileceklerinden farklı ya da daha yüksek resim, harç ve vergi uygulamayacaklardır. Dolayısıyla, vatandaşlığa alınma işlemlerinde, maliyet asgari düzeyde tutulmalı ve vatandaşlığa alınma prosedürleri hızlandırılmalıdır. Ayrıca, devletler, vatandaşlığa alınmanın kolaylaştırılması için diğer adımların da atılması yönünde teşvik edilmektedir. Vatandaşlığa alınmanın kolaylaştırılması için çeşitli önlemler alınabilir, gereken ikamet süresinin asgari düzeyde tutulması, eski vatandaşlığın terk edildiğine dair kanıt beklenmemesi gibi kolaylıklar sağlanabilir. ${ }^{121}$ Vatandaşlığı kazanmanın mümkün olduğunca kolaylaştırma süreci, yetkili makamların vatandaşlıkla ilgili kararlarında iyi niyetli davranma yükümlülüğü de gerektirir. ${ }^{122}$

Uluslararası belgelerde vatandaşlığın kazanılması ile ilgili doğrudan düzenlemeler yer almasa da, vatandaşlığın kazanılması ile ilgili birçok hakkın yer aldığı sözleşmeler vardır. Çocuklar için, 1989 tarihli Çocuk Haklarına Dair Sözleşme ile Kişisel ve Siyasal Haklar Uluslararası Sözleşmesi bunlara örnektir. Çocuk Haklarına Dair Sözleşmenin 7. maddesi, tüm çocukların vatandaşlık edinme hakkına; Kişisel ve Siyasi Haklar Sözleşmesi 24. maddede de çocukların vatandaşlık hakkına vurgu yapmaktadır. ${ }^{123} C E D A W$ 9. maddede tabiiyetin kazanılmasında, değiştirilmesinde veya muhafazasında kadınlara erkekler ile eşit haklar tanımakta ve özellikle bir yabancıyla evlenmenin veya evlilik sırasında kocanın tabiiyetini değiştirmesinin, kadının da otomatik olarak tabiiyet değiştirmesine tabiiyetsiz kalmasına veya kocanın tabiiyetini zorla

${ }^{120}$ Robinson, s. 64; Özkan, s. 395.

${ }^{121}$ Costa, s. 184.

${ }^{122}$ Grahl-Madsen, s. 147.

${ }^{123}$ Odman (2008), s. 179. 
almasına yol açmamasını düzenlemektedir. Yine maddenin ikinci fikrasında, taraf Devletler, çocukların tabiiyeti konusunda kadınlara erkeklerle eşit haklar sağlayacakları konusunda düzenleme getirmektedir.

1954 tarihli Vatansız Kişilerin Statüsüne İlişkin Sözleşme'nin 32. maddesinde, "Sözleşmeci Devletler, Vatansız kişileri özümlemeyi ve vatandaşlığa almayı mümkün olduğu ölçüde kolaylaştırırlar. Özellikle vatandaşlığa alma işlemlerini çabuklaştırmak ve bu işlemlerin masraf ve resimlerini mümkün olduğu ölçüde azaltmak için her türlü çabayı sarf ederler." ş̧eklinde düzenleme vardır. Bu haliyle madde, 1951 Sözleşmesinin 34. ve 29. maddesi ile paralel şekilde düzenlenmiştir. ${ }^{124}$ 1961 tarihli Vatansızlığın Azaltılmasına İlişkin Sözleşme 1. ve 4. maddelerinde, aksi takdirde vatansız kalacak bir kişiye sözleşmeci devletlerin vatandaşlık vermelerini öngören halleri düzenler. Sözleşmenin 5. ve 8. maddeleri ise, kişinin vatansız olmasını önlemek için âkit devletlerin yerine getirmesi gereken somut yükümlülükleri düzenlemektedir. ${ }^{125} \mathrm{Bu}$ düzenleme, mültecilerin vatansızlı̆̆ karşı korunması bakımından önemlidir.

Avrupa Birliği kapsamındaki vatandaşlığa dair düzenlemelere bakıldığında, Birlik içinde birçok tavsiye ve çözüm kararları benimsenmiştir. Genellikle odaklanılan nokta, vatandaşlığın kazanılmasının kolaylaştırılması için, yasal gerekliliklerin olabildiğince özgürlükçü yorumlanması gerekir. Gerekli ikamet süresinin kısaltılması, süreçte masraf ve geçen zamanın asgari tutulması, mevcut vatandaşlığın kaybına dair 1srarcı olunmaması buna örnek olarak gösterilebilir. ${ }^{126}$

1984'te yayımlanan AB Tavsiye Kararında, vatandaşlığın kazanılmasının, entegrasyon için hayati öneme sahip olduğuna ve vatandaşlığın kazanılması sürecinde kolaylaştırıcı önlemler alınması gerektiğine, bu kolaylaştırıcı önlemlerin ayrımcılık sayılamayacağ çünkü diğer kişilerden farklı olarak mültecilerin ülkelerinden veya diplomatik yollarla koruma ve destekten yoksun olduklarına vurgu yapılmaktadır. ${ }^{127}$

\footnotetext{
${ }^{124}$ Odman (2011), s. 41.

125 Odman (2011), s. 44.

${ }^{126}$ Costa, s. 185 (Bkz. Recommendation 654 (1969) on The Acquisition by Refugees of the Nationality of Their Country of Residence, European Consultative Assembly (September 30, 1969).

127 Costa, s. 185 (Recommendation 984 (1984) on the Acquisition by Refugees of the Nationality of the Receiving State, European Consultative Assembly (May 11, 1984).
} 
1997'de kabul edilen Avrupa Vatandaşlık Sözleşmesinin 6. maddesi üçüncü fikrasında, her taraf devletin, kendi iç hukukunda ve topraklarında, hukuken ve mutaden ikamet eden kişilerin vatandaşlığa alınmasını kolaylaştıracağı; vatandaşlığa alma koşullarını belirlerken, başvuru yapılmadan önceki ikamet şartının on yılı aşamayacağ 1 düzenlenmiştir. ${ }^{128}$ Dördüncü fikrada ise, her taraf devletin, kendi iç hukukunda, kendi topraklarında hukuken ve mutaden ikamet eden mülteci ve vatansızlar için kendi vatandaşlığının kazanımını kolaylaştıracağını düzenlemektedir.

\section{TÜRK HUKUKUNDA YEREL ENTEGRASYON ÇÖZÜMÜ}

\section{A) YUKK ve Uygulama Yönetmeliği ile Gelen Uyum Düzenlemesi}

Türkiye gerek Cumhuriyet öncesi dönemde, gerekse Cumhuriyetten sonra, Avrupa'dan veya Avrupa dışından, sığınma arayan insanların geldiği ülke olmuştur. ${ }^{129}$ Daha önce anlatılan çözüm türleri, Türkiye tarihi boyunca çeşitli zamanlarda uygulanmıştır.

1951 Sözleşmesine 1961 yılında, getirdiği coğrafi kısıtlama ile taraf olan Türk hukukunda, açıkça yerel entegrasyon adı altında hukuki bir düzenleme bugün de söz konusu değildir. Ancak, 11 Nisan 2014 tarihinde yürürlüğe giren 6458 sayılı Yabanc1lar ve Uluslararası Koruma Kanunu (YUKK) ile "uyum" adı altında, ekonomik ve mali imkânlar ölçüsünde, koruma statüsü alan kişilerin toplumla entegrasyonuna ilişkin, hukukumuza yeni bir düzenleme getirilmiştir. ${ }^{130}$

96. madde "(1) Genel Müdürlük, ülkenin ekonomik ve mali imkânları ölçüsünde, yabancı ile başvuru sahibinin veya uluslararası koruma statüsü sahibi kişilerin ülkemizde toplumla olan karşıllklı uyumlarını kolaylaştırmak ve ülkemizde, yeniden yerleştirildikleri ülkede veya geri döndüklerinde ülkelerinde sosyal hayatın tüm alanlarında üçüncü kişilerin aracıllı̆ olmadan bağımsız hareket edebilmelerini kolaylaştıracak bilgi ve beceriler kazandirmak amacryla, kamu kurum ve kuruluşları, yerel yönetimler, sivil toplum kuruluşları, üniversiteler ile

\footnotetext{
${ }^{128}$ Odman (2011), s. 59; Çiçekli, s. 382.

129 Cumhuriyet öncesi Osmanlı dönemi ve Cumhuriyet sonrası sığınma hareketlerinin gelişimi için bkz.: Kiriş̧̧i (1996), s. 2-6; Öztürk (2015), s. 347-356.

${ }^{130}$ Ekşi, s. 68.
} 
uluslararası kuruluşların öneri ve katkılarından da faydalanarak uyum faaliyetleri planlayabilir.

(2) Yabancılar, ülkenin siyasi yapısl, dili, hukuki sistemi, kültürü ve tarihi ile hak ve yükümlülüklerinin temel düzeyde anlatıldı̆̆ kurslara katılabilir.

(3) Kamusal ve özel mal ve hizmetlerden yararlanma, eğitime ve ekonomik faaliyetlere erişim, sosyal ve kültürel iletişim, temel sağllk hizmeti alma gibi konularda kurslar, uzaktan eğitim ve benzeri sistemlerle tanitım ve bilgilendirme etkinlikleri Genel Müdürlükçe kamu kurum ve kuruluşları ile sivil toplum kuruluşlarıyla da iş birliği yapılarak yayginlaştırilır."

Uyum başlığ 1 ile Türk hukukuna getirilen bu düzenleme, maddede sayılan kişiler için daha öncesinde bu şekilde bir düzenleme olmadığından önemlidir. Türk Dil Kurumu açıklamasına göre uyum, toplumsal çevreye veya bir duruma uyma, uyum sağlama, intibak, entegrasyon anlamına gelmektedir. ${ }^{131}$ Göç İdaresi Genel Müdürlüğü tarafından çıkartılan Türkiye ve Göç adlı kitapçı̆̆ın tanımlar kısmında ise uyum, göçmenlerin hem birey hem de grup olarak toplumun bir parçası kabul edildiği süreci ifade etmektedir. YUKK çerçevesinde uyum, toplumun ve göçmenin karşılıklı ve aynı ölçüde çaba göstereceği iki yönlü dinamik bir ilişki olarak ve göçmenlerin kendileriyle ilgili konularda edilgen olmadlğg aktif katılımcı bir süreç olarak planlanmakta, uyum programları ise isteğe bağll faaliyetler olarak tanımlanmaktadır. ${ }^{132}$

Maddede sayılan görevleri yapacak kurum Genel Müdürlüktür. Genel Müdürlük, YUKK madde 3/f.1-ğ bendine göre, Göç İdaresi Genel Müdürlügüdür. Yabancıların toplumla olan karşıl1klı uyumlarına ilişkin iş ve işlemleri yürütmek üzere Genel Müdürlüğün Uyum ve İletişim Dairesi görevlidir. ${ }^{133}$ Genel Müdürlük, ülkenin ekonomik ve mali imkânları ölçüsünde, maddede sayılanları yapacaktır. Peki, ülkenin ekonomik ve mali imkânları ölçüsü ile anlaşılması gereken nedir?

${ }^{131}$ Diğer tanım türleri için bkz.: www.tdk.gov.tr (Erişim Tarihi: 29.02.2016).

${ }^{132}$ T.C. İçişleri Bakanlığı Göç İdaresi Genel Müdürlüğü, Türkiye ve Göç, (Ankara: T.C. İçişleri Bakanlığı Göç İdaresi Genel Müdürlüğü Yayınları Pozitif Matbaa, 2013), s. 61. http://www.goc.gov.tr/icerik3/turkiye-ve-goc_564_565_886 (Erişim Tarihi: 01.03.2016).

133 Türkiye ve Göç, s. 34. http://www.goc.gov.tr/icerik3/turkiye-ve-goc_564_565_886 (Erişim Tarihi: 01.03.2016). 
Anayasanın ikinci maddesine göre Türkiye Cumhuriyeti Devleti sosyal bir hukuk devletidir. Sosyal devlet, gelir, barınma, eğitim, sağlık gibi konularda insan onuruna yaraşır asgari standartları güvence altına alma sorumluluğunu üstlenen devlet olarak tanımlanabilir. ${ }^{134}$ Ancak sosyal devletin yükümlülükleri sınırsız değildir. Devletin iktisadi ve sosyal ödevlerinin sinırlarının düzenlendiği Anayasa m. 65'te, "Devlet, sosyal ve ekonomik alanlarda Anayasa ile belirlenen görevlerini, bu görevlerin amaçlarına uygun öncelikleri gözeterek mali kaynaklarının yeterliliği ölçüsünde yerine getirir." denmektedir. Buna göre devlet, sosyal devlet olmasının getirdiği yükümlülüklerin hepsini birden değil, bu yükümlülüklerden amaçlarına uygunluklarına göre öncelikli olanları gözeterek ve mali kaynaklarının yeterliliği ölçüsünde yerine getirecektir. ${ }^{135}$ Keza maddede yer alan "ülkenin ekonomik ve mali imkânları ölçüsünde" ifadesi de, maddenin kişilere tanıdığı hakların kesin olarak sağlanmayacağı, ancak ülkenin ekonomik durumu ve imkânlarına göre uygulanacağını göstermektedir.

YUKK 96. madde kapsamındaki kişiler yabancılar, başvuru sahipleri ve uluslararası koruma statüsü kapsamında olanlardır. YUKK'un 3. maddesinde bu kavramların tanımları verilmiştir. Buna göre yabancı, Türkiye Cumhuriyeti Devleti ile vatandaşlık bağı bulunmayan kişiyi; başvuru sahibi, uluslararası koruma talebinde bulunan ve henüz başvurusu hakkında son karar verilmemiş olan kişiyi; uluslararası koruma statüsü kapsamında olanlar ise, mülteci, şartlı mülteci veya ikincil koruma statüsüne sahip olan kişiyi ifade eder.

Maddede bir kere yabancı dedikten sonra başvuru sahibi ve uluslararası koruma statüsü kapsamındaki kişilerin tekrar sayılmış olması gereksizdir, sayılan kişilerin hepsi hali hazırda yabancı kişilerdir. Maddede geçici koruma statüsü sahibi kişiler ise sayılmamıştır. Saymaktan maksat, bu kişiler dışındaki kişilerin uyum faaliyetlerinden yararlanamayacak olmalarına vurgu yapmaksa, bu düşünülemez. Çünkü söz konusu kişiler hakkında getirilen düzenleme, ister maddede sayılan kişiler isterse sayılmayan geçici koruma statüsü sahibi kişiler olsun, insan

${ }^{134}$ Uğur Kara ve Tolga Akkaya (Ed.), Temel Insan Hakları Bilgisi- I, (Eskişehir: T.C. Anadolu Üniversitesi Yayın1, 2012), s. 142.

${ }^{135} \mathrm{Bu}$ tarz bir kaydın anayasal norm haline gelmiş olması, sosyal hakların gereklerini yerine getirmek konusunda isteksiz davranan siyasal iktidarlar için önemli bir sığınak oluşturabileceğine dair eleştiri için bkz.: Kara, s. 82. 
hakları alanına ilişkin olup, haklarında tahdidi yoruma kapalıdırlar. $\mathrm{Bu}$ kişileri, belli haklardan mahrum bırakmak isteği, Kanunda açıça yazılmadığı müddetçe yorumla çıkarılamaz. Ayrıca, YUKK, ikinci kısımda "Yabancılar" ve üçüncü kısımda da "Uluslararası Koruma" şeklinde bir ayrıma giderek, geçici koruma statüsünü de üçüncü kısımda Uluslararası Koruma başlığı altında düzenlemiştir. Devamında dördüncü kısımda, "Yabancılar ve Uluslararası Korumaya İlişkin Ortak Hükümler" diyerek, kendisinden önceki kısımlarda düzenlenen kişiler için ortak düzenlemeler getirmiştir. Anılan sebeplerden dolayı, maddede sayılmamış olsalar bile, geçici koruma kapsamındaki kişiler de uyum faaliyetleri kapsamında yer alacaklardır.

Maddenin ilk fikrasında Genel Müdürlükten istenen, sayılan kişilerin, ülkemizde toplumla olan karşılıklı uyumlarını kolaylaştırmak ve ülkemizde, yeniden yerleştirildikleri ülkede veya geri döndüklerinde ülkelerinde sosyal hayatın tüm alanlarında üçüncü kişilerin aracılığı olmadan, bağımsız hareket edebilmelerini kolaylaştıracak bilgi ve becerilerin kazandırılmasıdır. Bu bilgi ve beceriler, kamu kurum ve kuruluşları, yerel yönetimler, sivil toplum kuruluşları, üniversiteler ile uluslararası kuruluşların öneri ve katkılarından da faydalanılarak yapılacaktır. $\mathrm{Bu}$ haliyle uyum ile planlanan, çalışmanın önceki bölümlerinde açıkladığımız, mültecinin kendi kendine yetebilmesi (self reliance) olarak görülmektedir. ${ }^{136}$

Maddenin son fikrasında, Genel Müdürlüğün, kamu kurum ve kuruluşları ile sivil toplum kuruluşlarıyla da iş birliği yaparak, kamusal ve özel mal ve hizmetlerden yararlanma, eğitime ve ekonomik faaliyetlere erişim, sosyal ve kültürel iletişim, temel sağlik hizmeti alma gibi konularda kursları yaygınlaştıracağı, uzaktan eğitim ve benzeri sistemlerle tanıtım ve bilgilendirme etkinlikleri yapacağı düzenlenmiştir. ${ }^{137}$

\footnotetext{
${ }^{136}$ Bkz. dn. 72 ve 73.

${ }^{137}$ T.C. İçişleri Bakanlığı Göç İdaresi Genel Müdürlüğü resmi internet sitesine bakıldığında, uyum faaliyetleri başlığı altında, YUKK'un farklı dillerde hazırlanıp yayımlandığı; farklı şehirlerde toplantılar düzenlenip yabancıların sorunları ve çözüm önerileri üzerinde tartışıldığı; yabancı öğrencilere bilgilendirme toplantısı yapıldığ 1 ; sığınmacı ve mültecilere yönelik uyum çalıştayı yapıldığı görülmektedir. Yapılan faaliyetlerin çoğu, özel anlamda yabancılara yönelik olup, doğrudan uluslararası koruma kapsamında yer alan kişilere yönelik detaylı çalışmalara rastlanılamamaktadır. http://www.goc.gov.tr/icerik3/uyum-faaliyetleri_409_564_565 (Erişim Tarihi: 01.03.2016).
} 
17 Mart 2016 tarihinde, Yabanc1lar ve Uluslararas1 Koruma Kanununun Uygulanmasına ilişkin Yönetmelik yayımlanmış ve yayımı tarihinde yürürlüğe girmiştir. 138 YUKK 96. maddedeki uyum düzenlemesi ile ilgili olarak, Yönetmeliğin 118. maddesinde yer almaktadır. YUKK 96. maddede yer alan kişiler ile Yönetmelik 118. maddesinde yer alan kişiler aynı olmakla birlikte, Yönetmelikte Kanundaki düzenlemeden farklı olarak, "yasal kalış imkânına sahip yabancı" ifadesi yer almaktadır. Genel Müdürlük, uyum faaliyetlerinin gerçekleştirilmesi için ilgili kurumlarla işbirliği yapacaktır. Maddenin üçüncü fikrasında, uyum faaliyetlerinin planlandığı ve yürütüldüğü, bünyesinde kamu kurum ve kuruluşlarının, belediyeler, ticaret odaları, sivil toplum kuruluşları ve üniversitelerin bulunduğu il göç kurullarının, vali başkanlığında ayda bir kez toplanacağı düzenlenmiştir. Yönetmeliğin uyum ile ilgili düzenlemesinde, Kanunda yer alan uyum düzenlemesi, daha anlaşılır hale getirilmemiştir.

B) Uyuma İlişkin Türk Hukukunda Yer Alan Diğer Düzenlemeler

Anayasa'nın 10. maddesinde herkesin dil, 1rk, renk, cinsiyet, siyasi düşünce, felsefi inanç, din, mezhep ve benzeri sebeplerle kanun önünde eşit olacağ düzenlenmiştir. Anayasa'nın 16. maddesinde ise, temel hak ve hürriyetlerin, yabancılar için, milletlerarası hukuka uygun olarak ve ancak kanunla sınırlanabileceğini düzenlemiştir. Ayrıca Anayasa 90. madde 5. fikrasında da, usulüne göre yürürlüğe konmuş milletlerarası anlaşmaların kanun hükmünde olduğu, söz konusu anlaşmaların temel hak ve özgürlüklerle ilgili olması halinde kanunlarla aynı konuyu farklı düzenlemiş olması halinde sözleşme hükümlerinin esas alınacağını söylemiştir.

YUKK düzenlemesinden önce uluslararas1 koruma statüsü kapsamındaki kişiler için kanun seviyesinde bir düzenleme yoktu. Türk hukukunda sığınmacı kavramı, Türkiye'ye İltica Eden veya Başka Bir Ülkeye İltica Etmek Üzere Türkiye'den İkamet İzni Talep Eden Münferit Yabancılar ile Topluca Sığınma Amacıyla Sinırlarımıza Gelen Yabancilara ve Olabilecek Nüfus Hareketlerine Uygulanacak Usul ve Esaslar Hakkında Yönetmelik ${ }^{139}$ ile düzenlenmekteydi. Söz konusu Yönetmelikte, YUKK'ta olduğu gibi bir uyum düzenlemesi

${ }^{138}$ RG. 17.03.2016- 29656. 
bulunmamaktaydı. YUKK ile söz konusu kişilerin ülkeye uyumunun kanun seviyesinde düzenlenmiş olması olumludur.

Zor durumdan kaçıp Türkiye'ye gelen sı̆̆ınmacıların ülkede bekleme süreleri uzadıkça eğitim, psikososyal sorunlar, dil konusundaki güçlükler, sağlık sorunları, uyum sorunları ve ekonomik sorunlar gibi sorunlarla karşılaşmaktadırlar. Bu sebeple bu kişilerin ülkede kaldıkları müddetçe, toplumla uyum içinde yaşaması kolaylaştırılmalıdır.

\section{Yasal İkamet ve Barıma Hakkı}

YUKK'ta, mülteci, şartlı mülteci ve ikincil koruma statüsü verilmiş kişilerin yasal ikametleri düzenlenmiştir. YUKK uyarınca, mülteci, şartlı mülteci ve ikincil koruma statüsü sahiplerine, uluslararası kimlik belgesi verilir ve bu belge ikamet izni yerine geçer (YUKK m. 76/4 ve 83/3). Geçici korumadan yararlanan kişilere, valilikler tarafindan geçici koruma kimlik belgesi verilir ve söz konusu belge, Türkiye'de kalış hakkı sağlar (Geçici Koruma Yönetmeliği m. 25). ${ }^{140}$

Barınma, insanın temel ihtiyaçlarından birisidir ve sosyal haklardandır. ${ }^{141}$ Türk hukukunda barınma hakkı anayasal bir haktır. 1982 Anayasasında, sosyal ve ekonomik haklar ve ödevler bölümünün 57. maddesinde konut hakkı düzenlenmiştir. Maddeye göre devlet, şehirlerin özelliklerini ve çevre şartlarını gözeten bir planlama çerçevesinde, konut ihtiyacını karşılayacak tedbirleri alır, ayrıca toplu konut teşebbüslerini destekler.

Uluslararası koruma kapsamındaki kişiler bakımından barınma hakkının düzenlenme şekline bakıldığında, YUKK'un 95. maddesinde öncelikle, başvuru sahibinin veya uluslararası koruma statüsü sahibi kişinin, barınma ihtiyaçlarını kendisinin karşılamasının esas olduğu, ancak Genel Müdürlükçe barınma ihtiyacının karşılanacağı barınma merkezlerinin kurulabileceği düzenlenmiştir. Barınma merkezlerinin kurulması, yönetimi ve işletilmesiyle ilgili usul ve esaslar yönetmelikle

\footnotetext{
${ }^{139}$ Yönetmelik için bkz.: RG. 30/11/1994 - 22127.

${ }^{140}$ Aysel Çelikel ve Günseli Öztekin Gelgel, Yabancılar Hukuku (21. Bas1), (İstanbul: Beta Yayınc1lık, 2015), s. 27.

${ }^{141}$ Aybay, 62.
} 
düzenlenecektir (YUKK m. 95/9). Konu ile ilgili yönetmelik, 22 Nisan 2014 tarihli Resmi gazetede yayımlanmıştır. ${ }^{142}$

Barınma merkezlerinde özel ihtiyaç sahiplerinin barındırılmasına öncelik verileceği ve özel ihtiyaç sahiplerinin kimler olduğu Yönetmelikte tanımlanmıştır. Düzenlemeye göre, başvuru sahibi ile uluslararası koruma statüsü sahibi kişilerden, refakatsiz çocuk, engelli, yaşl1, hamile, beraberinde çocuğu olan yalnız anne ya da baba veya işkence, cinsel saldırı ya da diğer ciddi psikolojik, bedensel ya da cinsel şiddete maruz kalmış kişi, özel ihtiyaç sahibidir ve barınma hizmetinin sağlanmasında kendilerine öncelik tanınır (Yön. m. 3/1-k).

Kabul ve barınma merkezi dışında ikamet eden başvuru sahibi veya uluslararası koruma statüsü sahibi kişiler ve aile üyeleri bu merkezlerde verilen hizmetlerden yararlandırılabilir (YUKK m. 95/5).

Türkiye'de 10 ayrı şehirde toplamda 25 adet barınma merkezi bulunmaktadır ve 18.12.2015 tarihi verilerine göre, geçici koruma kimlik belgeleri düzenlen 2.415.494 Suriyeliden 265.180 kişi 10 ilde kurulan 25 geçici barınma merkezinde, 2.150.314 Suriyeli ise barınma merkezi dışında bulunmaktadır. ${ }^{143}$

YUKK Uygulama Yönetmeliği 110. maddede başvuru sahibi ve uluslararası koruma statüsü sahiplerinin ikameti ve bildirim yükümlülüğü düzenlenmiştir. Maddenin ilk fikrasına göre Genel Müdürlük, başvuru sahibinin kayıt işlemi veya başvurusu sırasında ikamet edeceği illeri ve barındırılacağı yerleri belirleyebilecek ve gerekli hallerde değişiklik yapabilecektir. Bu belirleme sırasında, kişinin talebi, özel durumu, sağlık ve eğitim durumu ile akrabalık ilişkileri, kültürü, kişisel koşulları ve illerin kapasitesi göz önünde bulundurulacaktır. Şartlı mülteci ve ikincil koruma statüsü sahipleri için ikinci fikrada ayrı bir düzenlemeye gidilerek, söz konusu kişiler için barınılacak yerler Genel müdürlükçe belirlenecek veya Genel Müdürlük tarafindan belirlenen iller arasından bu kişiler yaşamak istedikleri ili seçebileceklerdir. Bu şekilde ayrı bir

${ }^{142}$ Kabul ve Barınma Merkezleri ile Geri Gönderme Merkezlerinin Kurulmas1, Yönetimi, İşletilmesi, İşlettirilmesi Ve Denetimi Hakkında Yönetmelik: RG. 22.04.201428980.

${ }^{143}$ T.C. İçişleri Bakanlığ 1 Göç İdaresi Genel Müdürlüğü, Geçici Koruma- Geçici Korumamiz Altındaki Suriyelilerhttp://www.goc.gov.tr/icerik6/istatistik_558_560_8971_icerik (Erişim Tarihi: 05.03.2016). 
düzenlemeye gidildiğinden, başvuru sahibi için bu şekilde bir seçim hakkının olmadığı sonucu çıkartılabilir. Nitekim başvuru sahiplerinin, akrabalık, sağlık veya diğer nedenlerle adres değişikliği taleplerinde bulunabilecekleri ve bu taleplerin Genel Müdürlük tarafindan değerlendirileceği ayrı olarak beşinci fikrada düzenlenmiştir. Maddenin üçüncü fikrasında ilgili kişilerin var olan adreslerini veya olası adres değişikliklerini en geç yirmi iş günü içinde, il müdürlüğüne bildirmeleri gerektiği düzenlenmiştir. Maddenin son fikrasında, maddenin mülteciler için de uygulanabileceği düzenlenmiştir. Eğer açıkladığımız gibi başvuru sahipleri için farklı, şartlı mülteci ve ikincil koruma statüsü sahipleri için yaşanacak yerin seçimi konusunda farklı uygulama söz konusu ise, mültecilerin bunlardan hangisi kapsamında değerlendirileceği açıkça düzenlenmeliydi görüşünü taşımaktayız.

Suriye'den Türkiye'ye sığınan kişilerden sorumlu birim olan T.C. Başbakanlık Afet ve Acil Durum Başkanlığı (AFAD), hepsinin topluca kamp olarak adlandırabileceği konteynırkent, çadır kent ve barınma merkezlerinde de birinci derecede sorumlu devlet kurumudur. ${ }^{144}$ AFAD'1n kamplarının bulunduğu 10 ilde, kamplarda ve kamp dışında yaşayanların anket soruları aracılığıyla katılımıyla gerçekleştirdiği saha çalışması sonuçlarına göre, kamp dişında yaşayan Suriyelilerin, \%74,1' $\mathrm{i}$ ev veya apartman dairelerinde; \%14'ü harabe binalarda; \%10,1'i geçici ya da plastik barınaklarda; \%0,8'i çadırlarda; \%0,6 kamu binalarında; \%0,4'ü de sokakta açık alanlarda yaşamını sürdürmektedir. ${ }^{145}$

Avrupa Komisyonunca hazırlanan Birinci Değerlendirme Raporunun ikinci bloğunda göç yönetimi düzenlenmiştir. İkinci blokta yer alan, "Suriye dlşından gelen mülteciler için yeterli kabul merkezlerinin oluşturulması ve bu merkezlerdeki standartların ilgili tüzüklere uyumlu olmasının sağlanması" şeklindeki 26. kriterde, kriterin bir bölümünün karşılandığ edilmiştir. $^{146}$

\footnotetext{
${ }^{144} \mathrm{AFAD}$ Afet Raporu: Suriye, https://www.afad.gov.tr/TR/IcerikDetay1.aspx? IcerikID=747\&ID=16 (Erişim Tarihi: 05.03.2016).

145 AFAD, Türkiye'deki Suriyeli Sı̆̆ınmacılar Saha Araştırması Sonuçları, s. 35. https://www.afad.gov.tr/Dokuman/TR/60-2013123015491-syrian-refugees-in turkey2013_baski_30.12.2013_tr. pdf(Erişim Tarihi: 05.03.2016).

146 İktisadi Kalkınma Vakfi, s. $1 \overline{2}$.
} 


\section{2. Çalışma Hakkı}

Çalışma hakkı, kişinin gelir sağlayabildiği bir iş sahibi olmasını güvence altına alan sosyal haklardandır ve dolayısıyla devlet, işsizlikle etkin biçimde mücadele etme, iş olanakları yaratma konusunda pozitif yükümlülükler altındadır. ${ }^{147}$

Anayasa, çalı̧̧ma hakkını 49. maddede ele almıştır. Çalışma hakkını düzenleyen söz konusu maddenin ilk fikra hükmüne göre, "Çalışma, herkesin hakkı ve ödevidir." Maddenin ikinci fikrasına göre ise, "Devlet, çalışanların hayat seviyesini yükseltmek, çalışma hayatın geliş̧irmek için çalışanları ve işsizleri korumak, çalışmayı desteklemek, işsizliği önlemeye elverişli ekonomik bir ortam yaratmak ve çalı̧̧ma barışını sağlamak için gerekli tedbirleri alır."

YUKK'ta iş piyasasına erişim, 89. maddenin 4. fikrasında düzenlenmiştir. F1krada, kişilerin sahip olduğu statülere göre ayr1 düzenlemelere gidilmiştir. Düzenlemeye göre, başvuru sahibi veya şartlı mülteci, uluslararası koruma başvurusu tarihinden altı ay sonra çalışma izni almak için başvurabilecek ve bu kişilerin çalışmasına ilişkin usul ve esaslar, Bakanlığın görüşü alınarak Çalışma ve Sosyal Güvenlik Bakanlığı tarafindan belirlenecektir. Mülteci veya ikincil koruma statüsü sahibi kişiler içinse, verilecek kimlik belgesi, çalışma izni yerine de geçer ve bu durum kimlik belgesine yazılır (m. 89/4-b). Mülteci veya ikincil koruma statüsü sahibi kişi, statü almasından itibaren, yabancıların çalışamayacağ iş ve mesleklere ilişkin diğer mevzuatta yer alan hükümler saklı kalmak üzere, bağımlı veya bağımsız olarak çalışabilir. ${ }^{148}$

Maddede, mülteci ve ikincil koruma statüsü sahibinin iş piyasasına erişimi, iş piyasasındaki durum ve çalışma hayatındaki gelişmeler ile istihdama ilişkin sektörel ve ekonomik şartların gerekli kıldığı hâllerde, belirli bir süre için, tarım, sanayi veya hizmet sektörleri, belirli bir meslek, iş kolu veya mülki ve coğrafi alan itibarılla sınırlandırılabileceği düzenlenmiştir. Ancak, Türkiye'de üç yıl ikamet eden veya Türk vatandaşıyla evli olan ya da Türk vatandaşı çocuğu olan mülteci ve ikincil koruma statüsü sahipleri için bu sınırlamalar uygulanmayacaktır (m. 89/4c).

${ }_{147}^{147}$ Aybay, s. 62; Kara, s. 81.

${ }^{148}$ Çelikel ve Öztekin Gelgel'e göre bu şekilde bir ayrıma gidilmesinin sebebi, şartlı mültecilerin, üçüncü bir güvenli ülkeye gönderilinceye kadar Türkiye'de uluslararası koruma statüsüne sahip olmalarıdır. Çelikel ve Öztekin Gelgel, s. 185. 
YUKK Uygulama Yönetmeliği 108. maddede "çalışma" başlıklı düzenleme mevcuttur. Maddenin ilk fikrası, Kanunun 89. maddesine atıf yaparak, başvuru sahibi veya uluslararası koruma statüsü sahibi kişilerin Türkiye'de çalışabileceğini düzenlemektedir. Başvuru sahibi veya uluslararası koruma statüsü sahibi kişilerin, iş piyasasına erişimlerinin Bakanlığın (İçişleri Bakanlığı) görüşü alınarak Çalışma ve Sosyal Güvenlik Bakanlığı tarafından belirlenecek usul ve esaslara göre olacağ maddenin ikinci fikrasında düzenlenmektedir.

26 Nisan 2016 tarihinde Uluslararası Koruma Başvuru Sahibi ve Uluslararası Koruma Statüsü Sahibi Kişilerin Çalışmasına Dair Yönetmelik ${ }^{149}$ Resmi Gazetede yayımlanmıştır. Yönetmeliğin 4. maddesi, bir nevi YUKK 89. maddenin 4. fikrasını tekrarlar niteliktedir. Maddeye göre, mülteci ve ikincil koruma statüsü sahibi kişiler bağımlı ve bağımsız olarak çalışır ve sahip oldukları kimlik belgeleri çalışma izni yerine geçer (m. 4/f. 1-2). Bu kişilerin statüsü sona erdiğinde veya kimlikleri herhangi bir suretle iptal edildiğinde, çalışma izinleri de sona erer. Başvuru sahipleri ve şartlı mülteci statüsüne sahip kişiler ise, çalışma izni almak zorundadırlar ve başvurusu uygun görülenlere çalışma izni verilir. Kişilerin sahip oldukları çalışma izinleri, başvuru sahipleri ve şartlı mültecilere ülkede mutlak kalış hakkı sağlamaz (m. 5/f. 1-2).

Türkiye'de bulunan sığınmacıların büyük bir kısmını oluşturan geçici koruma kapsamındaki Suriyeli sığınmacıların iş piyasasına erişimleri konusundaki hukuki düzenleme ise 22 Ekim 2014 tarihinde yayımlanan "Geçici Koruma Yönetmeliğidir". Yönetmeliği iş piyasasına erişimle ilgili 29. maddesinde "geçici koruma kimlik belgesine sahip olanların Bakanlar Kurulunca belirlenecek sektörlerde, iş kollarında ve coğrafi alanlarda çalışma izni almak için Çalışma ve Sosyal Güvenlik Bakanlı̆̆l'na başvurabileceği" belirtilmektedir. Yönetmelik usul ve esasların Çalışma ve Sosyal Güvenlik Bakanlığı'nca belirleneceğini belirtilmiştir ve "Geçici Koruma Sağlanan Yabancıların Çalışma İzinlerine Dair Yönetmeliğin ",50 15 Ocak 2016 tarihinde Resmi Gazetede yayınlanması ile konuya ilişkin somut bir adım atılmıştır.

15 Ocak 2016 tarihli Resmi Gazetede yayımlanarak yürürlüğe giren Yönetmelik, geçici koruma sağlanan yabancıların çalışma izni olmadan

${ }^{149}$ RG. 26.04.2016-29695.

${ }^{150}$ RG. 15.01.2016-29594. 
Türkiye'de çalışamayacaklarını ve çalıştırılamayacaklarını, aksine hareket edenler hakkında 4817 sayılı Kanun hükümlerini uygulanacağını belirtmektedir (Yön. m. 4/2). 4817 sayılı Kanun hükümleri uyarınca, kayıt dışı çalıştı̆̆ tespit edilen sığınmacıya $3.536 \mathrm{TL}$; çalışma izni bulunmayan sığınmacıyı çalıştıran işverenlere her bir sığınmacı için $8.848 \mathrm{TL}$; çalışma izni olmaksızın bağımlı çalışan sığınmacıya ise 881 TL para cezası uygulanacaktır. ${ }^{151}$

Geçici koruma sağlanan yabancılar, geçici koruma kayıt tarihinden altı ay sonra çalışma izni almak için Bakanlığa başvuruda bulunabilirler (Yön. m. 5/1). Başvurular, yabancıları çalıştıracak işveren tarafindan edevlet uygulaması üzerinden yapılır (Yön. m. 5/2). Ancak söz konusu yabancı, bağımsız çalışma iznine başvurma hakkına sahipse, başvuruyu kendisi de yapabilir (Yön. m. 5/3).

Yönetmeliğe göre mevsimlik tarım ve hayvancılık işlerinde çalışacak sığınmacılar çalışma izni olmadan çalışabilecektir, ancak bunun için ilgili valilikten muafiyet izni alınması gerekmektedir (Yön. m. 5/4). Muafiyet izninin çalıştıracak işveren tarafindan mı yoksa sığınmacılar tarafından $\mathrm{m}$ alınacağına ilişkin bir düzenleme yoktur. $\mathrm{Bu}$ alanda çalışacak sığınmacılar için Bakanlık tarafından il ve kota sınırlaması getirilebilecektir (Yön. m. 5/5).

Yönetmelik, bir üst sınır koyarak işletmelerde çalıştırılacak sığınmacı sayısının yerli işçilerin $\% 10$ nu geçemeyeceğini hükme bağlamıştır (Yön. m. 8/1). Bu üst limit işverenin bulunduğu yerin Çalışma ve İş Kurumu İl Müdürlüğünce son dört haftalık süre içinde aynı işi yaptıracak yerli işçi bulunamadığının belgelenmesi halinde istisnai olarak aşılabilecektir (Yön. m. 8/3). Bu düzenleme, sınır illerinde Suriyeli kişilerce açılan ve çalışanlarının tamamı Suriyeli işçilerden oluşan işletmeler açısından önemlidir. Bu noktada özellikle sığınmacı işçilerin yoğun olduğu sınır illerinde işgücü analizleri yapılması ile Yönetmelikte öngörülen $\% 10$ barajının hangi iş kollarında ve alanlarında aş1labileceğinin belirlenmesi gerekmektedir.

Yönetmeliğin kâr amacı gütmeyen dernek ve vakıfların geçici korumadan yararlanan yabancıları çalıştırmak üzere başvuru

${ }^{151}$ Çalışma ve Sosyal Güvenlik Bakanlığı (2016), 4817 Sayıl Kanunun 21. maddesi Gereğince Uygulanacak İdari Para Cezalart, http://www.calismaizni.gov.tr/html/kacakyabanc\%C4\%B1-isci-calistirma-cezasi/ (Erişim Tarihi: 06.03.2016). 
yapabileceklerine ilişkin düzenlemesi de, uygulamada ihtiyaç duyulan bir düzenlemedir (Yön. m. 11/1). Çünkü iltica ve göç alanında faaliyet gösteren kurumlar, öncelikle sığınmacıların içinden personel istihdamına ihtiyaç duymaktadır.

Yönetmelikte, İş Kurumu tarafından bir işyerinde mesleki eğitim ve işbaş1 eğitimi verilenlerin eğitim sonunda aynı işyerinde çalıştırılması için Bakanlığa başvurulabileceğini ve bu durumda işyeri istihdam kotasının farklı uygulanabileceğini belirtilmektedir (Yön. m. 12/1-2). Bu imkân sığınmacılar için olumlu bir düzenlemedir.

Yabancı Sağlık Meslek Mensuplarının Türkiye'de Özel Sağlık Kuruluşlarında Çalışma Usul ve Esaslarına Dair Yönetmeliğin ${ }^{152}$, "Suriye uyruklu sağlı meslek mensuplarının muafiyet durumu" başlığını taşıyan geçici 1. maddesine göre: "Suriye'de yaşanan olaylar sebebiyle Türkiye'de geçici koruma altına alınanlar için Afet ve Acil Durum Yönetimi Başkanlı̆̆ tarafindan kurulan barınma merkezlerinde çalışmak isteyen Suriye uyruklu sağllk meslek mensuplarl, mesleğini icraya yetkili olduğuna dair belge ibraz etmek kaydiyla 5 inci maddenin birinci fikrasinin (a), (b), (c) ve (d) bentlerindeki şartlardan muaf tutulur".

$\mathrm{Bu}$ madde uyarınca, geçici barınma merkezlerinde çalışmak isteyen Suriye uyruklu sağlık meslek mensupları, mesleklerini icraya yetkili olduklarına dair belgeyi sundukları takdirde, 5. madde a, b, c, d, bentlerinde yer alan diploma ve/veya uzmanlık belgelerinin denkliği onaylanmış ve Bakanlıkça tescilleri yapılmış bulunmak, mesleğini icra etmesine kanunen engel hali bulunmamak, Türkçe bilmek ve hekimler için, zorunlu mesleki malî sorumluluk sigortası yaptırmak şartlarından muaf olacaklardır. ${ }^{153}$

Avrupa Komisyonunca hazırlanan Birinci Değerlendirme Raporunun ikinci bloğunda göç yönetimi düzenlenmiştir. İkinci blokta yer alan, "Farklı statülere sahip sığınmacıların kimlik kartlarına ve işgücü piyasasına erişimlerinin sağlanması" şeklindeki 27. kriterde, kriterin bir

${ }^{152}$ RG. 22.02.2012-28212. Geçici koruma altına alınanlara sağlanan hizmetler ile ilgili bkz.: Nuray Ekşi, "Geçici Koruma Yönetmeliği Uyarınca Geçici Korumanın Şartları, Geçici Koruma Usulü, Sağlanan Haklar ve Geçici Korumanın Sona Ermesi”, İstanbul Barosu Dergisi, Cilt: 88, Say1: 6, 2014, s. 65-89, s. 75-77.

${ }^{153}$ Ekş̧i (2014), s. 76. 
bölümünün karşılandığ ettiği ifade edilmiştir. ${ }^{14}$

\section{3. Ĕ̈itim Hakkı}

Eğitim ve öğretim özgürlüğü Anayasanın 42. maddesinde herkes için güvence altına alınmakta ve ilköğretim bütün vatandaşlar için zorunlu k1lınmaktadır.

YUKK'un 89. maddesinde, başvuru sahibi veya uluslararas1 koruma statüsü sahibi kişi ve aile üyelerinin ilköğretim ve ortaöğretim hizmetlerinden yararlanacağı düzenlenmektedir (m. 89/1).

YUKK Uygulama Yönetmeliği 105. maddede, "eğitim ve ögretim" konusu düzenlenmiştir. Başvuru sahibi veya uluslararası koruma sahibi kişiler ve aile üyeleri, statülerini gösteren belgelerini ibraz ederek, ilköğretim ve ortaöğretim kurumlarındaki eğitim hizmetlerinden yararlanabileceklerdir (m. 105/1). Başvuru sahibi veya uluslararası koruma statüsü sahibi kişiler, Türkiye'de ön lisans, lisans, yüksek lisans veya doktora öğrenimi hakkı elde ettiler ise, ayrıca öğrenci ikamet izni almalarına gerek olmayacaktır (m. 105/3).

Türkiye, uyruğu ne olursa olsun tüm çocukların eğitim hakk1 olduğunu savunan Çocuk Hakları Bildirgesi'nin imzacısıdır. Bununla birlikte, ulusal mevzuatta Suriyeli mültecilerin Türkiye'de eğitim hizmetlerine erişimini düzenleyen iki belge bulunmaktadır. Bunlardan ilki Ekim 2014 tarihli Geçici Koruma Yönetmeliği, diğeri ise Yabancılara Yönelik Eğitme ve Öğretme Hizmetleri Genelgesidir. Geçici Koruma Kanunu Yönetmeliği'nin "eğitim hizmetleri" başlıklı 28. maddesi, yabancıların eğitim faaliyetlerinin geçici barınma merkezlerinin içinde ve dışında MEB'in kontrol ve sorumluluğunda yürütüleceğini belirtmektedir. Yükseköğrenim görme hakkına dair usullerin YÖK tarafından belirleneceği de Yönetmelik'te yer almaktadır. Genelge ise eğitim hizmetleri hakkında daha ayrıntılı bilgi vermektedir. Genelgede Suriyeli ve kayıtlı çocukların MEB'e bağlı ve Suriyelilere yönelik olarak oluşturulmuş Geçici Eğitim Merkezleri'nde eğitim alabilecekleri ve Suriyeli çocukların okula yerleştirilmeleri, eğitim haklarına erişimi konusunda da İl/İlçe Eğitim Komisyonları kurulacağı vurgulanmaktadır.

Çiçekli'nin yaptığı gözlemlerden verdiği bilgilere göre, "kamplarda kurulan kreş, anaokulu, ilkögretim ve liselerde Suriye müfredatını baz

\footnotetext{
${ }^{154}$ İktisadi Kalkınma Vakfi, s. 12-13.
} 
alan Suriyeli gönüllü ögretmenlerin de destek verdiği Arapça eğitim verilmekte, Türkçe dil eğitim dersleri de ek olarak sunulmaktadır. "155

\section{Vatandaşlığın Kazanılması}

1951 Sözleşmesinin 1. maddesinin (C) fikrasında altı bent halinde, mülteci statüsünün kaybedildiği durumlar düzenlenmiştir. Üçüncü bende göre, mülteci, yeni bir vatandaşlık kazanmışsa ve vatandaşlığını kazandığı ülkenin korumasından istifade ediyorsa, artık mülteci statüsü sona erecektir. Çünkü artık ulusal korumadan yararlanan kişinin, uluslararası korumaya ihtiyaç duymadığına inanılmaktadır. ${ }^{156}$

2008-2013 yılları arasında, aranan şartları sağlayarak Türk vatandaşlı̆̆ını kazanan Suriye uyrukluların sayısı toplam 3577'dir. ${ }^{157}$

Türk vatandaşlığının kazanılmasına dair düzenlemeler, 5901 sayılı Türk Vatandaşlığı Kanunu (TVK) ile İskân Kanununda yer almaktadır. İskân Kanununa göre, Türkiye'ye göçmen olarak kabul edilen Türk soylu ve Türk kültürüne bağlı kişiler, gerekli işlemlerin tamamlanmasından sonra Bakanlar Kurulu kararı ile vatandaşlığa alınırlar (İskân Kanunu m. 8/4).

5901 say1l TVK'ya göre vatandaşlik doğumla ve sonradan kazanılır (TVK m. 5/1). Doğumla kazanılan vatandaşlık, soy bağı veya doğum yeri esasına göre kurulur (TVK m. 6/1). Soy bağı esasına göre vatandaşlığın kurulması TVK m. 7'de düzenlenmiştir ve maddenin ilk fikrasına göre, Türkiye içinde veya dışında, Türk vatandaşı ana veya babadan evlilik birliği içinde doğan çocuk Türk vatandaşıdır. İkinci fikraya göre, anne Türk vatandaşı ise, evlilik birliği dışında doğan çocuk Türk vatandaşıdır. Üçüncü fikraya göre, Türk vatandaşı baba ve yabancı anadan evlilik birliği dışında doğan çocuk, babanın çocuk ile soy bağını kurması ile Türk vatandaşıı̆ını kazanır.

Doğum yeri esasına göre vatandaşlığın kurulması TVK m. 8'de düzenlenmiştir ve maddenin ilk fikrasına göre, Türkiye'de doğan ve yabancı ana ve babasından dolayı doğumla herhangi bir ülkenin vatandaşlı̆̆ını kazanamayan çocuk, doğumdan itibaren Türk vatandaşıdır.

\footnotetext{
${ }^{155}$ Çiçekli, s. 324.

${ }^{156}$ Odman (1995), s. 149; Altınışık ve Yıldırım, s. 26; Çelikel ve Gelgel, s. 126; Çiçekli, s. 273.

${ }^{157}$ Mültecilerle Dayanışma Derneği, Basın Açıklaması: Suriyeli Mültecilerin Seçimlerde Oy Kullanacağ http://www.multeci.org.tr/haberdetay.aspx?Id=85 (Erişim Tarihi: 06.03.2016).
} 
İkinci fikraya göre, Türkiye'de bulunmuş çocuk, aksi sabit olmadıkça Türkiye'de doğmuş sayılır. Yabanc1 ana veya yabanc1 babasından, soy bağı esası ile vatandaşlığı doğumla kazanan çocuk, Türkiye'de doğmuş olsa bile, buna dayanarak vatandaşlığı kazanamaz. ${ }^{158}$

Türk vatandaşlığının doğumla kazanılmasını, ülkede yoğun nüfusa sahip geçici koruma statüsü sahipleri için yorumlayacak olursak, TVK'nın 7. maddesine göre, anası Türk babası Suriye vatandaşı olan evlilik birliği içinde veya dışında doğmuş çocuk, doğumla Türk vatandaşlığını kazanacaktır. Anası Suriye vatandaşı babası Türk vatandaşı olan ve evlilik birliği içinde doğan çocuk da doğumla Türk vatandaşlığını kazanırken, evlilik birliği dışında doğan çocuk, ancak babanın çocuk ile soy bağını kurması ile Türk vatandaşlığını kazanacaktır. TVK'nın 8. maddesine göre, ana ve babasından herhangi bir ülkenin vatandaşlığını kazanamayan ve Türkiye'de doğmuş çocuk da, Türk vatandaşlığını kazanacaktır. Ekşi'nin verdiği örneğe göre, Suriye ordusuna karşı savaşmaları sebebiyle, Suriye vatandaşlığından atılan ve vatansız duruma düşen ana ve babanın Türkiye'de doğan çocuğu, Türk vatandaşlığını kazanacaktır. ${ }^{159}$

Türk vatandaşlığının sonradan kazanılması ise yetkili makam kararı ile evlat edinilme yolu ve seçme hakkı yolu ile gerçekleşmektedir. Türk vatandaşlığının yetkili makam kararı ile kazanılması üç şekilde gerçekleşmektedir; genel yolla kazanma, istisnai yolla kazanma ve yeniden kazanma. Türk vatandaşlığının genel yolla kazanılması için ilgilinin bazı şartları yerine getirmesi gerekmektedir. Bu şartlar, ergin ve ayırt etme gücüne sahip olma, başvuru tarihinden geriye doğru beş y1l Türkiye'de kesintisiz ikamet etmiş olma, Türkiye'de yerleşmeye karar verdiğini davranışları ile teyit etme, genel sağlı bakımından tehlike teşkil edecek hastalığı bulunmama, iyi ahlak sahibi olma, yeteri kadar Türkçe konuşabilme, Türkiye'de geçimini sağlayacak gelire veya mesleğe sahip olma ve milli güvenlik ve kamu düzeni bakımından engel teşkil edecek hali bulunmamadır.

Vatandaşlığın genel yolla kazanılmasını geçici koruma kapsamındaki kişiler için değerlendirecek olursak; vatandaşlı̆̆ın genel yolla kazanılması için kişinin başvuru tarihinden itibaren geriye dönük beş yıl yasal ve kesintisiz ikamet etme şartı yer almaktadır. Geçici koruma

\footnotetext{
${ }^{158}$ Gülin Güngör, Tabiiyet Hukuku (3. Bas1), (Ankara: Yetkin Yayınc1lı, 2015), s. 66.

${ }^{159}$ Ekşi, 2015b, s. 198-199.
} 
kapsamındaki kişilerin ikametine ilişkin hem Türk Vatandaşlığı Kanununun Uygulanmasına İlişkin Yönetmelik madde 16/2-c'de, hem de Geçici Koruma Kanunu'nun 25. maddesinde düzenleme bulunmaktadır. TVK Yönetmeliğine göre, yasal ikamet izni olmaksızın veya yasal olmakla birlikte Türkiye'de yerleşme niyetini göstermeyen; sı̆̆ınma veya iltica başvuru sahibi, sığınmact, öğrenim, turistik, öğrenim gören çocuğuna refakat, tedavi gibi amaçlarla ikamete bağlandiğı anlaşılan kişilerin başvurusu kabul edilmez ve bu husus yazılı olarak ilgilisine bildirilir. Geçici Koruma Yönetmeliğine göre ise, kayıt işlemi tamamlanan geçici koruma kapsamındaki kişilere kimlik belgesi verilir (Yön. m. 22/1). Geçici koruma kimlik belgesi, Türkiye'de kalış hakkı sağlar. Ancak bu belge, Kanunda düzenlenen ikamet izni veya ikamet izni yerine geçen belgelere eşdeğer sayılmaz, uzun dönem ikamet iznine geçiş hakk1 sağlamaz, süresi ikamet izni toplamında dikkate alınmaz ve sahibine Türk vatandaşlığına başvuru hakkı vermez (Yön. m. 25).

Geçici Koruma Yön. m. 25, geçici koruma kapsamındaki kişilerin genel yolla vatandaşlığın kazanılmasına başvuru yollarını tamamen kapatmaktadır. Vatandaşlığın genel yolla kazanılmasında en önemli hususlardan birisi, ülkede beş yıl yasal ve kesintisiz ikamet etme şartıdır. Geçici koruma sahiplerinin ülkede kaldıkları müddetçe korumanın kapsamında yer aldığı düşünülürse, koruma kapsamındayken sahip oldukları kimlik belgeleri yalnızca ülkede kalma hakkı sağlayacaktır ve söz konusu kalma süresi, ikamet izni toplamında da dikkate alınmayacaktır. Tüm bu engelleyici yolları sayan madde, en sonunda da açık bir ifadeyle kalma hakkı sahiplerinin vatandaşlık başvurusunda bulunsa bile ikamet şartını sağlamayacağından vatandaşlığ kazanamayacağını söylemektedir.

TVK'da Türk vatandaşlığının istisnai yolla kazanılması, 12. maddede üç bent halinde düzenlenmiştir. Milli güvenlik ve kamu düzeni bakımından engel teşkil edecek hali bulunmamak şartıyla Bakanlığın teklifi ve Bakanlar Kurulu kararı ile göçmen olarak kabul edilen kişiler (12/1-c), vatandaşlığa alınması zaruri görülen kişiler (12/1-b) ve Türkiye'ye belli alanlarda hizmeti geçen veya geçeceği düşünülen kişiler (12/1-a) Türk vatandaşlığını kazanabilirler. İstisnai yolla vatandaşlığın kazanılması için ilgilinin isteği ve Bakanlar Kurulunun kararı gerekir ve 
Bakanlar Kurulu, istisnai vatandaşlı̆̆a alınma şartlarına sahip olan kişilerin taleplerini, kanunda olmayan sebeplerle reddedemez. ${ }^{160}$

1951 Sözleşmesi 34. maddesinde, devletlere getirilen, mültecileri vatandaşlığa alma işlemlerinde kolaylık sağlama yükümlülügüü, hukukumuzda başkaca hüküm getirilene kadar, vatandaşlığa alınması zaruri kişiler olarak görülebilirler. ${ }^{161} 2011$ 'de 25,2012 'de 44 ve 2013 'ün ilk 6 ayında 9 kişi olmak üzere toplam 78 Suriye uyruklu kişi 5901 sayılı Türk Vatandaşlı̆̆ Kanununun 12. maddesinde öngörülen hükümler çerçevesinde Türk vatandaşlığına alınmıştır. ${ }^{162}$

Evlenme, kişinin vatandaşlığını doğrudan etkilemez. Türk vatandaşlığının evlenme yoluyla kazanılması TVK 16. maddesinde düzenlenmiştir. Maddeye göre, bir Türk vatandaşı ile üç yıldan beri evli olan ve evliliği devam eden yabancılar Türk vatandaşlığını kazanmak üzere başvuruda bulunabilir. İçişleri Bakanlığı'nın verilerine göre, bu şekilde 2008-2013 yılları arasında evlilik yoluyla vatandaşlık kazanan Suriye uyrukluların toplam sayıs 2543 'dür. ${ }^{163}$

Türk vatandaşlığının sonradan kazanılmasının bir diğer yolu da evlat edinilme ile kazanılmasıdır. TVK'nın 17. maddesine göre, bir Türk vatandaşı tarafindan evlat edinilen ergin olmayan kişi, milli güvenlik ve kamu düzeni bakımından engel teşkil edecek bir hali bulunmamak şartı ile Türk vatandaşlığını kazanabilir.

\section{SONUÇ}

Kişinin menşe ülkesi korumasından faydalanamayıp, başka bir ülkenin korumasına sığındığı uluslararası koruma uygulaması, gerek 1951 Sözleşmesi ve 1967 Protokolü, gerek başka birçok insan hakları belgelerinde düzenlenmiştir. Ancak, kişinin bu sığınma halinin sürekliliği istenmeyen bir durumdur ve bu durumun, sığınan kişinin onurlu yaşam sürmesini sürekli hale getirecek şekilde sonlandırılması arzu edilir.

\footnotetext{
${ }^{160}$ Vahit Doğan, Türk Vatandaşlık Hukuku, (Ankara: Savaş Yayınevi, 2014), s. 75.

161 Güngör, bunun sebebini "5901 sayıl1 Türk Vatandaşlığı Kanununun Uygulanmasına İlişkin Açıklamada" sözü edilen "uluslararası ilişkilerin" icabına dayandırmaktadır. Güngör, s. 101.

${ }^{162}$ Dönemin İçişleri Bakanı Muammer Güler'in açılaması için bkz.: http://www.milliyet.com.tr/iste-turk-vatandasliginagecen/siyaset/detay/1797106/default.htm (Erişim Tarihi: 08.03.2016).

${ }^{163}$ Mültecilerle Dayanışma Derneği, http://www.multeci.org.tr/haberdetay.aspx?Id=85 (Erişim Tarihi: 08.03.2016).
} 
Doktrindeki kabul gören üç nihai çözümden biri olan yerel entegrasyon, çoğu zaman ülkesine dönemeyen ve başka ülkeye de yerleşemeyen kişiler açısından tek çözüm yoludur.

Yerel entegrasyonun hukuki sürecinde, sığınan kişiye, bulunduğu ülkede vatandaşa yakın haklar ve bazı zamanlarda da vatandaşlığın kazanılması sağlanır. Tüm bu haklar, mülteci sözleşmelerinde düzenlenmelerinin yanı sıra, birçok insan hakları belgesinde de herkes için tanınmış haklardır ve taraf devletlerin bu sözleşmeler sebebiyle uluslararası sorumlulukları bulunmaktadır.

Türk hukukunda 2014 tarihinde yürürlüğe giren YUKK ile birlikte uluslararası koruma kapsamında yer alan kişiler ve yabancılar için getirilen "uyum" düzenlemesiyle, bu kişilerin topluma entegre olmaları amaçlanmaktadır. Topluma entegre olmanın hukuki sürecinde bu kişilere sosyal haklarının sağlanması gereklidir. Çalışmada bu kapsamda yasal ikamet ve barınma hakkı, çalışma hakkı, eğitim hakkı ve vatandaşlığın kazanılması incelenmiştir.

Türkiye topraklarında YUKK kapsamındaki kişilere bakıldığında genelinde yabancılar ve özelinde geçici koruma statüsü sahibi insan sayısı oldukça fazladır. Bu kişilerin barınma hakkı, sosyal devletin gerektirdiği ama imkânlarının el verdiği ölçüde Türkiye Devleti tarafından, karşılaştırıldığında diğer devletlerden oldukça daha kapsamlı bir şekilde yürütülmekteyse de, kişi sayısının oldukça fazla olması, yine de çoğu insanın barınma hakkından faydalanamadığını göstermektedir. Çalışma hakkı bakımından incelediğimizde, konu ile ilgili Yönetmelik çıkması, uygulama açısından oldukça önemlidir. Ancak sayıca fazla ve çoğu zaman bir geliri de olmayan bu insanlara yönelik Yönetmelikte kimi alanlarda $\% 10$ kotasının uygulanmaması veyahut ilgili nüfusun fazla olduğu şehirlerde bu kotanın aşılabilmesinde esneklik tanınması, amaca uygun olacaktır. Eğitim hakkı bakımından konuyu incelediğimizde, eğitim imkânları daha çok barınma merkezlerinde yoğunlaşmış durumdadır ve barınma merkezi dışında bulunan kişiler de dışarıdan gelerek bu imkândan faydalanabilmektedirler. Eğitim alanında entegre olmayı sağlamak ve eğitimsiz bir nüfusun oluşumunu engellemek için, dil konusunda çalışmalara ağırlık verilmelidir.

Vatandaşlığın kazanılması hususuna gelecek olursak, açıkça geçici koruma sahiplerinin vatandaşlığ kazanamayacaklarına dair bir düzenleme olmamakla birlikte, özellikle vatandaşlığın genel yolla kazanılmasında 
aranan beş yıl ikamet şartı ve geçici koruma sahiplerinin yasal bir ikamet izninin olmayışı, genel yolla vatandaşlık edinimini fiili olarak imkânsız kılmaktadır. Ancak bu kişilerden Türk soylu ve Türk kültürüne bağlı olanlar İskân Kanununa göre; diğerlerinin de TVK hükümleri uyarınca istisnai yoldan veya evlenme yolu ile vatandaşlı̆g kazanmalarında herhangi bir engel yoktur.

\section{KAYNAKÇA}

$\underline{\text { Kitaplar }}$

Acer, Yücel/ Kaya, İbrahim ve Gümüş, Mahir, Küresel ve Bölgesel Perspektiften Türkiye'nin Iltica Stratejisi, (Ankara: USAK Yayınlar1, 2010).

Altınışı, Çiğdem ve Yıldırım, Mehmet Şahin, Mülteci Haklarının Korunması, (Ankara: Ankara Barosu Yayınları, 2002).

Aslan, Volkan, “Amerikalılar Arası İnsan Hakları Sistemi”, İnönü Üniversitesi Hukuk Fakültesi Dergisi, Cilt:3 Sayı:2 Y11 2012.

Aybay, Rona, Insan Hakları Hukuku, (İstanbul: Bilgi Üniversitesi Yayınlar1, 2015).

Batur Yamaner, Melike, Silahlı Çatışmalarda Sivillerin Korunması, (İstanbul: Arıkan Yayınevi, 2007)

Büyükçalık, Mürvet Ece, Mülteci Hukuku'nun Gelişimi ve Türkiye'de Mültecilerin Sosyal Haklarl, (İstanbul: On İki Levha Yayınları, 2015).

Çelikel, Aysel ve Gelgel, Öztekin Gülseli, Yabancılar Hukuku (21. Bası), (İstanbul: Beta Yayınc1lık, 2015).

Çiçekli, Bülent, Yabancılar ve Mülteci Hukuku, (Ankara: Seçkin Yayınevi, 2014).

Doğan, Vahit, Türk Vatandaşlık Hukuku (12. Bas1), (Ankara: Savaş Yayinevi, 2014).

Eggli, A. V., $\quad$ Mass Refugee Influx and the Limits of Public International Law (Hollanda: Martinus Nijhoff Publishers 2002).

Ekşi, Nuray, "Geçici Koruma Yönetmeliği Uyarınca Geçici Korumanın Şartları, Geçici Koruma Usulü, Sağlanan Haklar ve Geçici Korumanın Sona Ermesi", İstanbul Barosu Dergisi, Cilt: 88, Say1: 6, 2014, s. 65-89. 
Ekşi, Nuray, "İnsan Hakları Avrupa Mahkemesi Kararlarında Sığınmacı Ve Mültecilerin Türkiye'den Sınırdışı Edilmelerini Engelleyen Haller", İstanbul Barosu Dergisi, Cilt: 82, Say1: 6, 2008, s. 2801-2838.

Ekşi, Nuray, "Suriyelilere Toplu Olarak Türk Vatandaşlığ1 Verilebilir Mi?", İstanbul Barosu Dergisi, Cilt: 89, Sayı:2, 2015b, s. 196-202.

Ekşi, Nuray, Yabancılar ve Uluslararası Koruma Hukuku (3. Bası), (İstanbul: Beta Yayıncılık, 2015).

Feller, E., Türk, V. ve Nicholson, F. (der.), UNHCR's Global Consultations On International Protection, Refugee Protection in International Law - (Cambridge: Cambridge University Press, 2003).

Grahl-Madsen, Atle, Commentary on the Refugee Convention 1951, UNHCR, Division of International Protection, (Geneva, 1997).

Güneysu, Gökhan, Çevrenin Silahlı Çatışmalar Esnasında Korunması, (Ankara: Adalet Yayinevi, 2014).

Güngör, Gülin, Tabiiyet Hukuku, Gerçek Kişiler-Tüzel Kişiler-Şeyler (3. Bas1), (Ankara: Yetkin Yayınevi, 2015).

Hathaway, James C., The Rights Of Refugees Under International Law, (Cambridge University Press, 2005).

İktisadi Kalkınma Vakfı, Türkiye ile Vize Serbestliğine Illişkin Yol Haritast- Birinci Değerlendirme Raporu Analizi, (IKV, 2014).

Kara, Uğur ve Akkaya, Tolga (Ed.), Temel İnsan Hakları Bilgisi- I, (Eskişehir: T.C. Anadolu Üniversitesi Yayını, 2012).

Kirişçi, Kemal, Türkiye "Coğrafi Sintrlama”yı Kaldirlyor mu? Türkiye'de Kasım 1994 Siğınma Yönetmeliği, (Ankara: Sı̆̆ınmacı ve Göçmenlerle Dayanışma Derneği, 1996).

Odman, Tevfik, Çocuk Hakları Bă̆lamında Çocuk Mülteciler, (Ankara: Çağ Üniversitesi Hukuk Fakültesi Yayınları, 2008).

Odman, Tevfik, Mülteci Hukuku, (Ankara: İmaj Yayınevi, 1995).

Odman, Tevfik, Vatansızların Hukuki Durumu ve Türk Hukuku, (Ankara: Çağ Üniversitesi Hukuk Fakültesi Yayınları, 2011). 
Özcan, Mehmet, Avrupa Birliği Sığınma Hukuku- Ortak Bir Sĭ̆ınma Hukukunun Ortaya Çıkışı, (Ankara: USAK Yayınları, 2005).

Özgür, Nurcan ve Özer, Yeşim, Türkiye'de Sığınma Sisteminin Avrupalılaştırılması, (İstanbul: Derin Yayınları, 2010).

Özkan, Iş11, Göç, Ilttica ve Siğınma Hukuku, (Ankara: Seçkin Yayınc1lik, 2013).

Öztürk, Neva Övünç, "Avrupa Birliği Temel Haklar Şartında Yer Alan Sı ̆̆ınma Hakkının Tahlili” İn̈nü Üniversitesi Hukuk Fakültesi Dergisi, Cilt:3 Sayı:2, 2012.

Öztürk, Neva Övünç, Mültecinin Hukuki Statüsünün Belirlenmesi, (Ankara: Seçkin Yayınevi, 2015).

Pazarc1, Hüseyin, Uluslararası Hukuk Dersleri II. Kitap, (3. Bası), (Ankara: Turhan Kitabevi, 1993).

Taneri, Gökhan, Uluslararası Hukukta Mülteci ve Siğınmacıların Geri Gönderilmemesi (Non-Refoulement) Illkesi, (Ankara: Bilge Yayınevi, 2012).

Tütüncü, Ayşe Nur, İnsancıl Hukuka Giriş, (İstanbul: Beta Yayınevi, 2006).

United Nations High Commissioner for Refugees, An Introduction To International Protection Protecting Persons of Concern To UNHCR Self-Study Module 1, (Geneva: UNHCR, 2005b).

Uzun, Elif, "Geri Göndermeme (Non-Refoulement) İlkesinin Uluslararas1 Hukuktaki Konumu Üzerine Bir Değerlendirme", Uluslararası Hukuk ve Politika, Cilt: 8, Say1:30, 2012, s. 25-58.

Internet Kaynaklarl

Adalet Bakanlığı, Uluslararası Hukuk ve Dışişleri Genel Müdürlüğü, http://www.uhdigm.adalet.gov.tr/sozlesmeler/coktarafl isoz/bm1.html (Erişim Tarihi: 03.03.2016).

AFAD, Afet Raporu: Suriye, https://www.afad.gov.tr/TR/IcerikDetay1.aspx ?IcerikI $\mathrm{D}=747 \& \mathrm{ID}=16$ (Erişim Tarihi: 05.03.2016).

AFAD, Türkiye'deki Suriyeli Sığınmacılar Saha Araştırması Sonuçları. https://www.afad.gov.tr/Dokuman/TR/602013123015491-syrian-refugees-in-turkey- 
2013_baski_30.12.2013_tr.pdf (Erişim Tarihi: 05.03.2016).

BMMYK Türkiye ve Türk İçişleri Bakanlığı, İltica ve Göç Mevzuatı, (Ankara: Başkent Matbaası 2005), s. 224. http://www.goc.gov.tr/files/files/iltica_goc.pdf (Erişim Tarihi: 19.02.2016).

Costa, Rosa da (2006). Rights of refugees in the context of integration: legal standards and recommendations. UNHCR Legal and Protection Policy Research Series. http://www.unhcr.org/44bb90882.pdf (Erişim tarihi: 12.02.2016).

Global Consultations (2002). Strengthening and expanding resettlement today: dilemmas, challenges and opportunities, http://www.refworld.org/docid/3d62679e4.html (Erişim Tarihi: 12.02.2016).

Çalışma ve Sosyal Güvenlik Bakanlığı (2016), 4817 Sayılı Kanunun 21. Maddesi Gereğince Uygulanacak İdari Para Cezaları, $\mathrm{http}: / / \mathrm{www}$.calismaizni.gov.tr/html/kacakyabanc\%C4\%B1-isci-calistirma-cezasi/ (Erişim Tarihi: 06.03.2016).

Delegation of the European Union to Turkey, Uzun dönem ikamet izni verilenlere ilişkin $\mathrm{AB}$ direktifi uluslararası korumadan yararlananlar ile mültecileri kapsayacak şekilde genişletildi. http://www.avrupa.info.tr/tr/bilgikaynaklari/haber-arsivi/news-single-view/article/uzundoenem-ikamet-izni-verilenlere-iliskin-ab-direktifiuluslararasi-korumadan-yararlananlar-ile.html (Erişim Tarihi: 20.02.2016).

Executive Committee of the High Commissioner's Programme, "Note on International Protection", A/AC.96/830, 7 September 1994. http://www.refworld.org/docid/3f0a935f2.html (Erişim Tarihi: 14.02.2016).

Mültecilerle Dayanışma Derneği, Basın Açıklaması: Suriyeli Mültecilerin Seçimlerde Oy Kullanacağı ve Maaş Aldıkları İddialarına Dair, 27.03.2014. http://www.multeci.org.tr/haberdetay.aspx?Id=85 (Erişim Tarihi: 06.03.2016). 
Robinson, N. (1997). Convention relating to the Status of Refugees: Its history, contents and interpretation. UNHCR, Geneva. http://www.unhcr.org/3d4ab67f4.pdf (Erişim Tarihi: 17.02.2016).

Rona Aybay, Açıklamalı İnsan Hakları Evrensel Bildirisi, Türkiye Barolar Birliği Yayınlar1 http://tbbyayinlari.barobirlik.org.tr/TBBBooks/insan_h aklari_evrensel_bildirisi.pdf (Erişim Tarihi: 13.02.2016).

Statute of the Office of the United Nations High Commissioner for Refugees, General Assembly Resolution 428 (V) of 14 December $1950, \quad$ s. 4. http://www.unhcr.org/3b66c39e1.html (Erişim Tarihi: 19.02.2016).

T.C. İçişleri Bakanlığı Göç İdaresi Genel Müdürlüğü, Geçici KorumaGeçici Korumamız Altındaki Suriyeliler- İstatistikler. http://www.goc.gov.tr/icerik6/istatistik_558_560_8971 _icerik (Erişim Tarihi: 05.03.2016).

T.C. İçişleri Bakanlığı Göç İdaresi Genel Müdürlüğü, Türkiye ve Göç, (Ankara: T.C. İçişleri Bakanlığı Göç İdaresi Genel Müdürlüğü Yayınları Pozitif Matbaa, 2013), s. 61. http://www.goc.gov.tr/icerik3/turkiye-vegoc_564_565_886 (Erişim Tarihi: 01.03.2016).

UN High Commissioner for Refugees (UNHCR), Global Consultations on International Protection/Third Track: Local Integration, 25 April 2002a, EC/GC/02/6, http://www.refworld.org/docid/3d6266e17.html (Erişim Tarihi: 12.02.2016).

UN High Commissioner for Refugees (UNHCR), Global Consultations on International Protection/Third Track: Strengthening and Expanding Resettlement Today: Dilemmas, Challenges and Opportunities, 25 April 2002b, $\mathrm{EC} / \mathrm{GC} / 02 / 7$,

http://www.refworld.org/docid/3d62679e4.html (Erişim Tarihi: 12.02.2016).

UNHCR (2005). Handbook for self-reliance, s. 1. http://www.unhcr.org/44bf7b012.pdf (Erişim Tarihi: 11.02.2016). 
UNHCR Core Group on Durable Solutions, Framework for Durable Solutions for Refugees and Persons of Concern,(Geneva: UNHCR, 2003a) http://www.refworld.org/docid/4124b6a04.html (Erişim Tarihi: 16.02.2016).

UNHCR, Agenda for protection (3. Basim). UNHCR, 2003b http://www.unhcr.org/3e637b194.html (Erişim Tarihi: 16.02.2016).

UNHCR, Handbook for self-reliance, (Geneva: UNHCR, 2005a), s. 1. http://www.unhcr.org/44bf7b012.pdf (Erişim Tarihi: 11.02.2016).

United Nations High Commissioner for Refugees (UNHCR); Department of International Protection (DIP); Protection Information Section (PIS), "UNHCR Master Glossary of Terms", June 2006, Rev.1. http://www.refworld.org/docid/42ce7d444.html (Erişim Tarihi: 14.02.2016).

Zümray Kutlu, Bekleme Odasından Oturma Odasına- Suriyeli Mültecilere Yönelik Çalışmalar Yürüten Sivil Toplum Kuruluşlarına Dair Kısa Bir Değerlendirme, Açık Toplum Vakfi. http://www.aciktoplumvakfi.org.tr/medya/02062015be klemeodasi.pdf (Erişim Tarihi: 05.03.2016).

\section{KISALTMALAR CETVELI}
AB
: Avrupa Birliği
ABÖ
: Afrika Birliği Örgütü
AFAD
:T.C. Başbakanlık Afet ve Acil Durum Başkanlığı
Bkz. (bkz.)
BM
BMESK
BMMYK
: Bakınız
: Birleşmiş Milletler
:Birleşmiş Milletler Ekonomik ve Sosyal Konseyi
:Birleşmiş Milletler Mülteci Yüksek
Komiserliği 
CEDAW

Der.

Dn. (dn.)

Ed.

f.

ILO

İKV

M. (m.)

RG

S.

s.

TBMM

TC

TVK

UN

UNHCR

Yön.

YUKK
:The Convention on the Elimination of All Forms of Discrimination against Women (Kadınlara Karşı Her Türlü Ayrımcılığın Önlenmesi Uluslararası Sözleşmesi)

: Derleyen

: Dipnot

: Editör

: Fikra

:The International Labour Organization (Uluslararası Çalışma Örgütü)

: İktisadi Kalkınma Vakfi

: Madde

: Resmi Gazete

: Say1

: Sayfa

: Türkiye Büyük Millet Meclisi

: Türkiye Cumhuriyeti

: Türk Vatandaşlığı Kanunu

: United Nations (Birleşmiş Milletler)

:United Nations High Commissioner for Refugees (Birleşmiş Milletler Mülteci Yüksek Komiserliği)

: Yönetmelik

: Yabancılar ve Uluslararası Koruma Kanunu 